University of Louisville

ThinkIR: The University of Louisville's Institutional Repository

1942

\title{
A study of visiting teacher work at the Highland Junior High School for the school year 1940-1941.
}

Mary C. Newman

University of Louisville

Follow this and additional works at: https://ir.library.louisville.edu/etd

Part of the Education Commons

\section{Recommended Citation}

Newman, Mary C., "A study of visiting teacher work at the Highland Junior High School for the school year 1940-1941." (1942). Electronic Theses and Dissertations. Paper 1837.

https://doi.org/10.18297/etd/1837

This Master's Thesis is brought to you for free and open access by ThinkIR: The University of Louisville's Institutional Repository. It has been accepted for inclusion in Electronic Theses and Dissertations by an authorized administrator of ThinkIR: The University of Louisville's Institutional Repository. This title appears here courtesy of the author, who has retained all other copyrights. For more information, please contact thinkir@louisville.edu. 
UNIVERSITY OF LOUISVILLE

A STUDY OF VISITING TEACHER WORK AT THE HIGHLAND JUNIOR HIGH SCHOOL FOR THE SCHOOL YEAR 1940-1941.

\author{
A Dissertation \\ Submitted to the Faculty \\ Of the Graduate School of the University of Louisville \\ In Partial Fulfillment of the \\ Requirements for the Degree \\ of Master of Arts
}

Department of Education

By

Nary C. Newman

Year

1942 
NAME OF STUDENT: MARY C. NEWMAN

TITLE OF THESIS: A STUDY OF VISITING TEACHER

WORK AT THE HIGHTAND JUNIOR

HIGH SCHOOI FOR THE SCHOOL

YEAR 1940 - 1941

APPROVED BY READING COMMITTEE COMPOSED OF THE FOLLOWING NEMBERS:

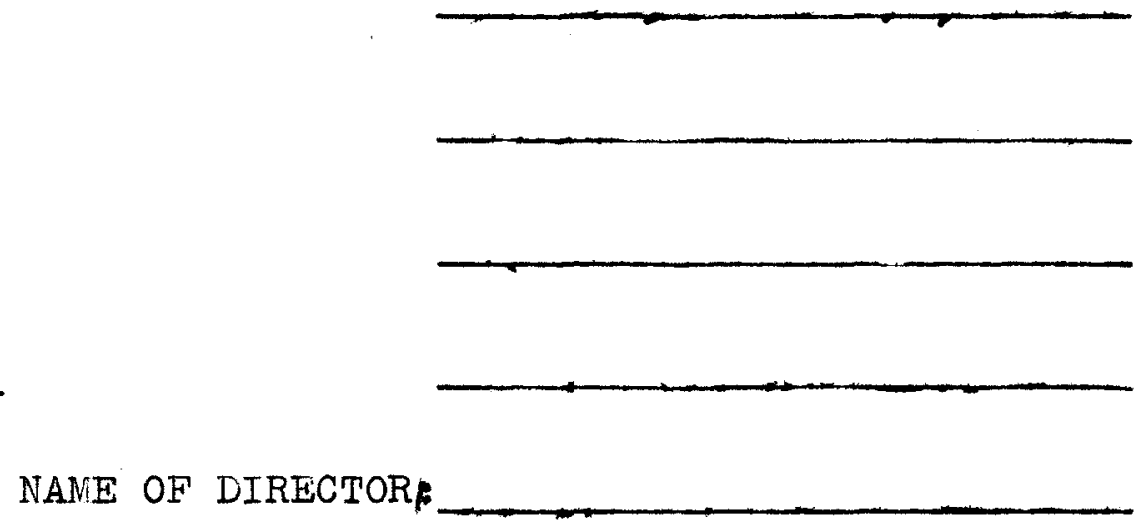

DATE: Qugust 17,1942 
I THE IIGHLAND JUNIOR HIGH SCHOOL AND ITS DISTRICT • • • • • • • • • • • •

The Highland Junior High School and Its Administration . . . . . .

The Personnel of the Highland Junior High School . . . . . . . . 28

Concepts of Visiting Teacher Work . 35

The Visiting Teacher in Louisville

and at the Hiehland Junior High

School . . . . . . . . .

The Selection of the Visiting Teacher Group . . . . . . . . . •

The Selection of the Normal Group . •

A Comparison of The Normal Group And The Visiting Teacher Group . . . . 
ii1

CHAPTER

PAGE

$$
\begin{aligned}
& \text { Teachers' Estimates of Results of } \\
& \text { Cases............... } 109
\end{aligned}
$$

IV SUMNARY AND CONCLUSIONS . . . . . . 119

BIBLIOGRAPHY . . . . . . . . . . . 122 


\section{LIST OF TABLES}

TABLE

PAGE

I

TYPICAL PROGRAN OF STUDIES AND PERIODS

PER WEEK AT FIGHLAND JUNIOR HIGH SCHOOL

FOR THE YEAP 1940-194I • . . . . . . 16

II NUMEER OF TEACHLFS AT HIGHIAND JUNIOK

HIGH SCHOOL, 1940-1941, BY SUBJECTS • • 30

III NUMBER OF CASES BY CAUSES OF REFIRRAL FOR

WFICF HONE VISITS WERE MADE BY THE VISIT-

ING TEACHER AT TEE HIGHLAND JUNIOR HIGH

SCHOOL FOR TIE SCHOOL YEAR 1940-1941 • .

IV

SOTRCES OF REEERRALS OF TFE SIXTY VISIT-

ING TEACETR CASES AT THE HIGHLAND JUNIOR

HIGH SCHOOL FOR THE YEAR 1940-1941 . . •

$\mathrm{V}$ DISTRIBUION OF BOYS' MENBEFSHIP OF TFE HIGHLAND JUNIOR FICH SCHOOL, MAY 31, 1941, ACCORDING TO ECONONIC GROUP AND GRADE, WITH NUNBER AND PER CENT OF SAMPLES FROM $\mathrm{EACH}$. . . . . . . . . . . . . .

VI DISTRIBUTION OF GIRIS' NENBERSFIP OF THE HIGELAND JUNIOR FIGH SCHOOL, MAY 31, 1941, ACCORDING TO ECONOMIC GROUP AND GRADE;, 
TABLE

WITH NUMBER AND PER CENT OF SANPLES FROM $\mathrm{EACH} \cdot$. . . . . . . . . . . . .

62

VII COMPARISON OF PUPILS OF THE NORNAL GROUP WITH THOSE OF THE VISITING TEACHER GROUP AT THE FIGHLAND JUNIOR HIGF SCHOOL AS THEY ARE DISTRIBUTED IN NUNBER, PER CENT, AVERAGE AGE, INTELLIGENT QUOTIENT NEDIANS AND RANGES, BY GRADBS AND SEX, FOR THE YEAR 1940-194I . . . . . . . . . . .

VIII COMPARISON OF RESUITS OF SIMS SCORE CARD FOR SOCIO-ECONONIC STATUS OF THE NORNAL GROUP WITH THE VISITING TEACER GROUP AT THE HIGHIAND JUNIOR HIGH SCHOOL FOR THE YEAR 1940-1941 . . . . . . . . . 73

IX CONPARISON OF TFT SIMS SCORE CARD RATINGS OF THE NORMAL GROUP AND THE VISITING TEACHER GROUP WITH THE ECONOMIC RATINGS OF IEE PRINCIPAL AND THE VISITING TEACHER 77

$X$ COMPARISON OF SCHOOLING OF PARENTS OF NORMAI GROUP WITH THE VISITING TEACHER GROUP AT THE FIGHLAND JUIOR HIGH SCHOOL FOR THE YEAR 1940-1941 
XI COMPARISON OF BROKINN HONES, WORKING MOTHERS, AND FATHERS IRREGULARIY AT HONE BFCAUSE OF THEIR EMPLOYMENT OF THE NORMAL GROUP WITH THE VISTTING TEACHER GROUP AT THE HIGHIAND JUNIOR HIGH SCHOOL FOR THE YEAR 1940-1941 . . . . . . .

XII COMPARISON OF HOMES OF NORMAL GROUP WITH VISITING TEACHER GROUP OF THE HIGHIAND JUNIOR HIGE SCHOOL FOR THE YEAR 1940-1941

XIII COMPARISON OF OUT-OF-SCHOOL ACTIVITIES OF NORMAL GROUP WITH THE VISITING TEACFER GROUP AT THE HIGHLAND JUNIOR HIGH SCHOOL FOR THE YEAR 1940-1941 . . . .

XIV CONPARISON OF TIE PERCENTAGE OF PUPILS WHO PARTICIPATED IN EXTRA CURRTCUIAR ACTIVITIES OR RECEIVED SPECIAL HONORS OF THE NORNAL GROUP WITH THE VISITING TEACHER GROUP OF THE HIGHLAND JUNIOR HIGH SCHOOI FOR THE YEAR 1940-1941 • . . . . . . 90

XV PER CENT OF PHYSICAL DHFECTS OF PHE NORMAL GROUP AS COMPARED WITH THE VISITING TEACHER GROUP OF PUPILS AT THE HIGHIAND JUNIOR HIGH 
XVI COMPARISON OF NUMBER OF PHYSICAL DEFECTS PER CASE OF NORNAL CASES WITH VISITING TEACHER CASES AT THE HIGHIAND JUNIOR HIGE SCHOOL FOR THE YEAR 1940-1941 ... • • •

XVII COMPARISON OF SCHOOL ATTENDANCE OF THE NORMAL GROUP WITH VISITING TEACHER ATTENDANCE CASES AT THE HIGHLAND JUNIOR HICH SCHOOL FOR THE SCHOOI YEAR 1940-194I . . . . 99

XVIII COMPARISON OF NUNBER OF PUPIIS WHO FAILED IN ONE OR MORE SUBJECTS BY TERMS OF THE WORMAL GROUP WITH THE VISITING TEACHER GROUP AT THE HIGHLAND JUNIOR HIGH SCHOOL FOR THE YEAR 1940-1941......... 104

XIX COMPARISON OF NTMBER OF SUBJECT FAILURES OF THE NORMAI GROUP WITH THE VISITING TEACFER GROUP AT THE HIGHLAND JUNIOR HIGH SCHOOL FOR TEE YEAR 1940-1941 •.... 105

XX CONPARISON OF IMPROVEMENT IN TEACHERS ' GRAD: OF THE NORMAL GROUP WITH THE VISITING TEACHER GROTP AT THE HIGHLAND JUNIOR HIGH SCHOOL FOR THE YEAR 1940-1941 . . • 106 
vi1i

TABIE

PAGE

XXI TEACHERS ' JUDGMENT OF RESULTS OF THE SIXTY

VISITING TEACHER CASES AT THE FIGHIAND

JUNIOR HIGH SCHOOL FOR PHE YEAR 1940-1941

111

XXII TEACHERS' JUDGNENT OF VISITING TEACHER'S

SERVICES AND OTHER FACTORS RESPONSIBLE FOR

INPROVENENT OF CASES DTRING PHE SCHOOL

YEAR 1940-1941 AT THE HIGHLAND JUNIOR HIGH

SCHOOL . . . . . . . . . . . .

XXII TEACHERS' JUDGMENT OF IMPROVEMLNT SHOWN IN

DIFFERENT AREAS, DUE TO VISITING TEACHER

SERVICES AT THE HIOHLAND JUNIOR EIGH SCHOOL

FOR THE YHAR 1940-1941 . . . . . . . 


\section{LIST OF FIGURES}

FIGURE

PAGE

I MAP OF HIGHLAND JUNIOR HIGE SCHOOI

DISTRICT • • • • • • • • • • • • 
A Study of Visiting Teacher Work at the HighIand Junior High School for the School Year 1840-1941 was uncertalen for the following purposes: first, to determine the visiting teacher's contributio. to better school adjustment of a group of sixty cases; and second, to point out practices by which the visiting teacher might widen her activities and extend the field of her services in this particular school.

A comparative study of the group of sixty visitIng teacher cases and of a sample of the school, a normal group, is the princlpal basis for this work. As many different areas as possible, dealing both with the pupil's school life and with his out-of-school life, are considered in the comparison so that a wide basis for judging differences in the groups would be obtained. The extent to which the child is educated by a varfety of influences outside of his school makes it necessary for school workers to have an understanding of chijdren in the light of their social background and their membership in the home and the community. The areas examined in this study are intended to bring out as many different influences as possible so that particular weakness in either froup will be apparent. The comparisons are based upon school records of pupils and a 
questionnaire for socio-economic status rating answered by pupils of each group.

The comparison made of attendance and scholarship of the two groups, and a questionnaire answered by the classrocm teachers are used in an attempt to judse certain aspects of the visiting teacher's services. While chlldren are much the same everywhere and their problems are similar, and while the same fundamental principles of discovering and dealing with these problems are everywhere applicable, the particular local environment of home, school, and community have definite bearing upon the specific treatment which the visitine teacher must utilize in carrying out her work. Therefore, in this study, the first part of the thesis is concerned with the nature of the district and the character of the school.

Even though this study is confined to one year, it mey be considered a cross section of the work as it is carried on over a period of years. One year is a comparatively short time in the field of case work. Some of the sixty cases have been active with the visiting teacher since the early elementary grades, while others have developed during the current year and have needed only short treatment. 
THE HIGHLAND JUNIOR FIGH SCHOOL

AND ITS DISTRICT 


\section{CHAPTER I}

\section{THE HIGHLAND JUNIOR HIGH SCHOOL AND ITS DISTRICT}

In this chapter an attempt will be made to present a picture of the function of the visiting teacher in the schools of Louisville, Kentucky, with particular reference to the Highland Junior High School. Such a picture is essential for an adequate interpretation of the data or results of a study of cases handled by the visiting teacher at the Highland Junior High School during the school year 1940-1941. Insight into visiting teacher work in a given school requires a knowledge and understanding of the community and of the entire school situation, as well as a clear idea of the general concepts of visiting teacher work. This chapter, therefore, also describes the school district, the administration and personnel of the school itself, and the philosophy underlying general visiting teacher practices.

The first two junior high schools to be opened in Loulsville, Kentucky, were Highland Junior High School and Western Junior High School. They were opened the second semester of the school year 1927-1928. In the report of the Superintendent of Schools for the years 1925-1926, the following is written in regard to the inauguration of the junior high schools: 
The shortage in pupil accommodation has grown to more than 8,000 and this situation caused more than 22,000 pupils to suffer the effects of congestion. The enroliment of pupils in grades seven, eight, and nine, approximately equaled the shortage of seats. lhis situation gave the Board of Ecucation an opportunity to achieve two oreat improvements for the public schools, that is, to eliminate congestion and to inaugurate junior high schools in Louisville.l

During 1940-1941 there were nine junior high schools belonging to the Louisville Public School system. The installation of juntor high schools was not an isolated act but part of the movement which had as its objective the remaking of the school system in terms of the modern conception of the true function of a school. The junior high school moverient in the United States, which grew out of the need for educational reform, was actuated by clearly defined aims and purposes. Comparatively early in the junior high school movement, Briggs listed the following aims and purposes, which are today, as well as they were then, ideals toward which all junior high schools aspire

1. To continue, in so far as it may seem wise and possible, and in a gradually decreasing degree, common integrating education.

1 Superintendent of Schools, Fifteenth Report of the Board of Education, (Louisvilie, Kentucky: From JuIy 1925 to June 30,1926$)$. 
2. To ascertain and reasonably to satisfy pupils' inportant immediate and assured future needs.

3. To explore by means of materials in themselves worth-while, interests, aptitudes, and capacities of pupils.

4. To reveal to pupils, by materials otherwise justifiable, the possibilities in the major fields of learning.

5. To start each pupil on the career which as a result of the exploratory courses, he, his parents, and the school are convinced is most likely to be of profit to him and to the state. 2

The Highland Junior High School is located in the eastern part of Louisville, Kentucky. The city has a population of $319,072^{3}$ and covers an area of approximately forty square miles. 4 The school accommodates seventh, eighth, and ninth grade pupils living in this section of the city in an area of approximately two hundred and eleven clty blocks. 5

2 Thomas H. Briggs, The Junior High School (Boston: Houghton Mifflin Company, $\overline{1920), ~ p p . ~} \overline{162-175 .}$

3 United States Bureau of Census, Sixteenth Census of the United States 1940 (Washington, D. C.: Un1ted States Government Printing Office, 1941), p. 43.

4. Works Projects Administration, Real Property Survey and Low Income Housing Area Survey 1938-1939 TVolume I, $193 \overline{9}$, project pamphlet), p. $\frac{16}{16}$

5 New Nap of Greater Louisville, Kentucky.

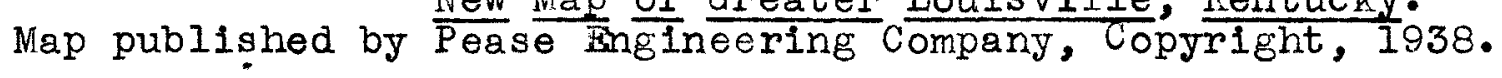


The District

The boundary lines of the Highland Junior High

School as shown on the map on Page 6 are as follows:

Northern: Lexington Road and Beargrass Creek. From intersection of Charlton and

Lexington Road east (not including

Lexington Road) to Beargrass Creek, to intersection of Creek and City

Limits.

Eastern: City Limits

Southern: City Limits

Western: Barrett Avenue and Highland Avenue. From intersection of Barrett and City Limits (near Royal Avenue) north (including Barrett) to H1ghland then east (including Highland), to Dudley, then in direct line across Cave Hill Cemetery to intersection of Charlton and Lexington Road.

Optional

Territory: Between Easterm, Highland, and Louisville Junior High Schools. The entire Shelby School district. 6

In the optional territory, only that part in which pupils live who usually attend Highland Junior High

School is included on the map. This territory is an extension of the district already described. The northern boundary line is Barrett Avenue; the easterm, is the clty Iimits; the western is Rufer Avenue and the southern is Beargrass Creek.

\footnotetext{
6 Assistant Superintendent of Elementary EducationSchool District Lines (Superintendent's Office, Louisville Public School System, 1938).
} 
County territory adjacent to the city limits is shown on this map because ninth grade pupils in this territory usually attend this school. As the county schools in this vicinity are maintained for pupils throvgh the eighth grade only, the county pays tuition of pupils in the clty schools from the ninth through the twelfth grades. 


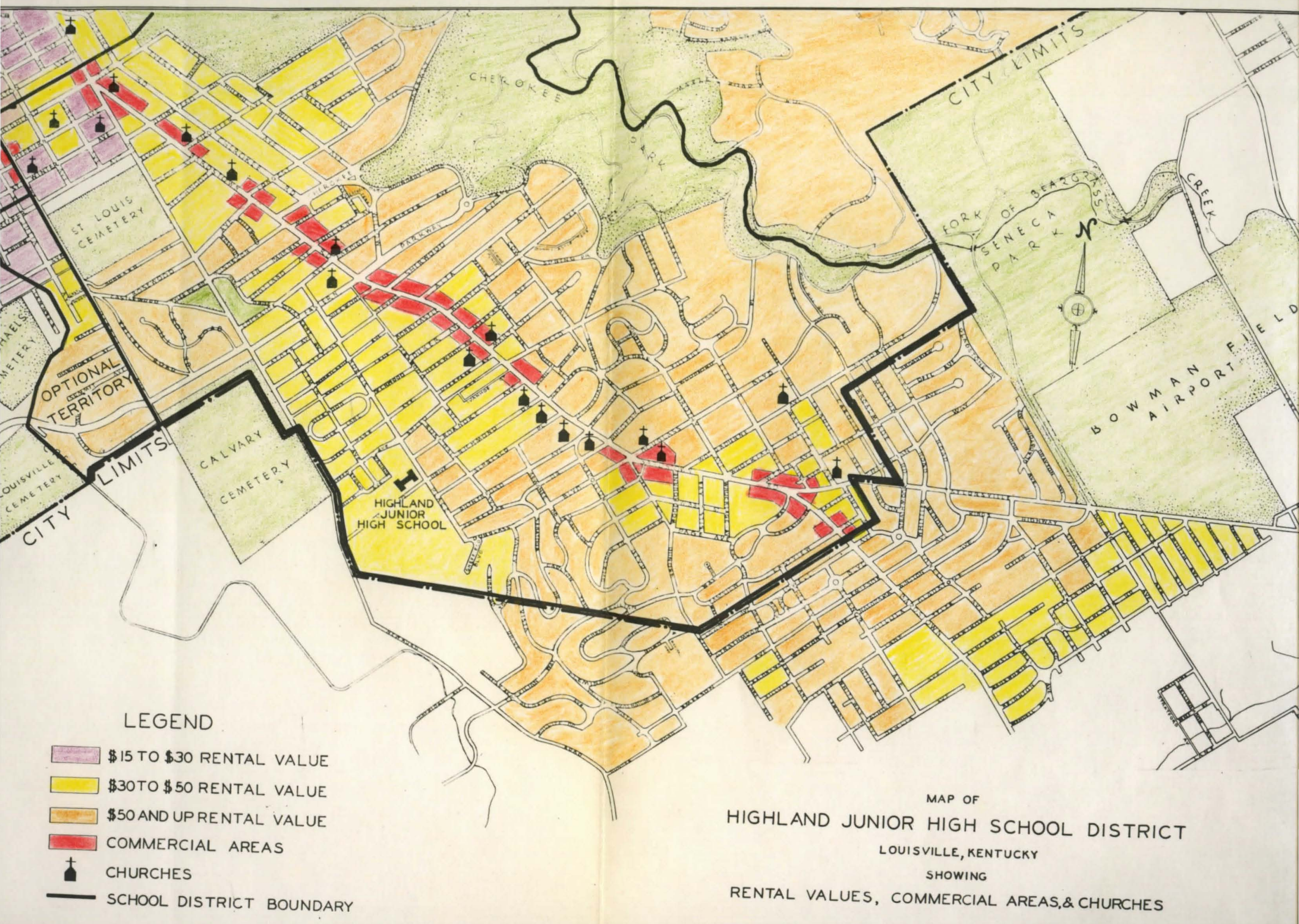


The Highland Junior High School section is composed of a residential district with one major commercial thoroughfare, Bardstown Road, running from north to south. Most of the stores, shops, and other commercial enterprises are located along this thoroughfare or immediately adjacent to 1t. There is, however, a small commercial center located in the northwestern part of the district on Barrett Avenue, and another at Eastern Parkway and Baxter Avenue. East of Bardstown Road, the property adjacent to and in Cherokee Park is probably the most expensive residential property in the city, while along Bardstown Road, in houses which have been converted into business places, residential units are usually of the lowest price in the district; between these two extremes are to be found residential units of all types.

This district, which includes practically the entire section known as "The Hichlands", has most of the shops and stores necessary to make it independent of the downtown shopping district. This trend seems to be growing. Ladies' and children's wearing apparel stores, shoe stores, furniture stores, and restaurants are some of the growing enterprises indicating this decentralization.

In a pamphlet published by The Courier-Journal and The Louisville rimes, a study of rental values of the Highland Junior High School district shows there are approx- 
imately five and a half city blocks in the fifteen to thirty dollar rental zone, and one hundred and two city blocks in the thirty to fifty dollar rental zone. Fiftyfive per cent of the city's fifty dollar and up rental zone lies in this district.?

There are 2933 rental occupied dwelling units, and 3819 owner occupled dwelling units in the Hichland. Junior High School district. ${ }^{8}$ Seventy-seven per cent of the dwelling units are owner occupied. In a survey made by the Works Projects Administration in 1937, it was found that for the city as a whole residential structures are almost equally divided between owner occupied and non-owner occupied groups. 9 Thus, this district has a lare percentage of home ownership combined with property commanding comparatively high rent.

In this district there are two public parks. Cheroke Park, covering 409.3 acres, combines natural beauty with a well-planned system of driveways trroush

7 The Courier-Journal and Louisville Times, Kentuckiana .... Its Potentialities, (Iouisvilie, Kentucky: The courier-Journal and The Louisvilie Times, 1941), P. 17 .

8 Caron Directory Company, Louisville Directory 1941 (Louisvil]e, Kentucky: Caron's Directory Company, Published, 1941), pp. 2068-2434. $1, \mathrm{p} .34$.

9 Works Projects Aaminjstration, op. cit., Vol. 
picturesque settings. It has an eighteen hole golf course, tennis courts, bridle paths, pavilions, and playground facilities. Tyler Fark, covering 12.6 acres, has recreational facilities including tennis courts and playground equipment. During the summer months a playground instructor, supplied by the Recreational Division of the Welfare Department of the City, is in charge. Other recreational features sponsored by the Recreational Division in the district are dancing classes for girls at the Belknap School, physical education classes for women, and basketball leagues for men at the Highland Junior High School.

In this district are located three elementary pubIic schools, which have been previously mentioned. These schools have classes from the kindergarten through the sixth grade. There are also three parochial schools having classes from the first through the elghth grade, and three private schools, two of which are for girls, with grades from the kindergarten through the twelfth grades, and one for boys,with grades from the seventh through the twelfth. of the eighteen churches in the district, three are Roman Catholic; two, Christian; two, Church of Christ; two, Lutheran; two, Presbyterian; two, Baptist; two, Methodist-Episcopal; one, Evangelical; one, Episcopal; and one, Latter Day Saints.

Boy and Girl Scout Troops are very popular with 
chilcren in this district. There are nine Boy Scout Troops in different sections of the district, open to boys from twelve years of age and up. Two hundred and eighteen boys are members of these groups. The "cub" troops, open to boys from nine through eleven years, have seven troops, numbering one hundred and thirteen members. "Explorer Units", including boys fifteen years of age and over, have two troops numbering fifteen members. ${ }^{10}$ Girl Scout activities in the district are carried on by eleven groups of "Intermediates", ages from ten to fourteen; six groups of "Brownies", ages seven to ten years, and one group of "Seniors" for girls over fourteen. These groups number two hundred and eighty-eight members. ${ }^{11}$ Six hundred and nineteen boys and girls between the ages of seven and eighteen are registered members of scout organizations in the Highland Junior High School district.

The Highland Branch Library is located at the lower end of the district. Its circulation was 88,777 for the year 1940-1941, the second largest circulation of the eight branch libraries for whites in the city for the year

10 Boy Scouts of America, Louisville Area Council (Files in office, 1941).

II Girl Scouts of America, Louisville Area Council (Files in office, 1941). 
1940-1941. The non-fiction circulation was 26,545 , the largest among this group. ${ }^{12}$ Community activities may be held in avallable rooms in the library bullding as long as they are of a non-political and non-denominational character. Among the activities which took place here during 1940-1941 were civic and social club meetings, piano rec1tals, language classes, story hour, and puppet shows. There are two moving picture theaters located in the district and a third is being built.

The Lakeside Swimming Quarry is a popular recreational feature during the summer months in the Highlands. It is open to the public upon payment of a small admission fee.

The protective agencies for the district are two fire houses and the Highland Branch of the police department.

Disorganizing forces in the community are comparatively few. Four cafes, allegedly the successors of the saloons are located here, while there are several small shops known as "beer joints". These shops usually depend upon the sale of beer, soft drinks, and sandwiches, and upon a percentage of "take" from the "juke boxes" and "pin

12 Yearly Report of Louisville Free Public Iibrary for Year 1940-1941 (Files of Louisville Free Public Library). 
ball" machines. In some instances these shops are the popular meeting place for the youth of the nelghborhood. Drug stores which have "pin ball" machines are often popular loitering places for groups of school age boys.

A study of juvenile delinquency in the city for 1935 was made by the Works Projects Administration. ${ }^{13}$ The juvenile delinquents include all juveniles appearing before the juvenile court. During that year there were 368 male white and 98 female white juvenile delinquents in the city. Only two of these were in the Highland Junior High School district. 14

This study of the district demonstrates that this is a high type residential district with a predominance of home owners and comparatively high rental dwellings. There is a majority of influences that tend to promote organization within a community, with a minimum of the disorganizing elements and little juvenile delinquency.

\section{The Highland Junior High School} and Its Administration

In this district, the Highland Junior High School is located at Norris Place, Speed, and Kichmond Avenues.

13 Works Projects Administration, A Study of Juvenile Delinquency in Louisville, 1935 - spot Map. Files of Community Chest.

$$
14 \text { Loc. cit. }
$$


The building, of colonial architecture, has five fully equipped manual training and household arts rooms, and three fully equipped science laboratories. Also among the features of the building are a modern auditorium, a gymnasium with girls' and boys' shower rooms, a cafeteria with kitchen faclities, a library containing approximately 6,000 volumes, medical rooms, rest rooms for men and women teachers, toilet and wash rooms on each floor for pupils, janitors' rooms, storage rooms, a general office, and a principal's office. The site of eight and a half acres on which the three story colonial building is located gives ample room for a large recreational field. After school hours and during week-ends, the field is used as a neighborhood playground. Thus, the physical aspects of the Highland Junior High School are found to be ample for carrying on a diversifled program, a program suited to the needs of adolescents. The program of studies provided for students at Highland Junior High School is essentially the same as in all other junior high schools in the Louisville Public School System. It is based upon the principle of certain constant courses required by all pupils, which are carefully selected and set down as requirements for all, and variable courses from which the different individuals may select in keeping with their needs and interests. Pringle, in his book on the junior high school, states that this 
type of curriculum organization is found in nearly all senior and junior high schools. ${ }^{15}$ In the seventh grade, exploratory courses in which pupils may find interests and aptitudes are prescribed, while the elective courses offered in the eighth and the ninth grades, have exploratory purposes. In regard to this Pringle has to say:

The plan of having constants and varlables provides for the greatest degree of freedom of cholce on the part of pupils and parents. It furnishes a flexibility helpful for pupils who have not made an occupational choice; and it permits pupils to use electives as try out courses, thus contributing to the exploratory function of the school.16

The constants in junior high schools of the

Lovisville Public School System are English, mathematics, social studies, general science, and physical education. In Table $I$ is a typical program of studies for each grade showing number of periods per week for each subject. The programs were those used during the second semester. Slight deviations from this program are usually necessitated for reasons of organization and administration or in cases of special programs for individual cases.

Each grade has two divisions, $B$ indicating the

15 Ralph W. Pringle, The Junior High School A Psychological Approach (New York: McGraw-Hill Book Company, Inc.1937, p.103.

16 Loc. cit. 
first half of the grade and $A$ indicating the second half. The school day is divided into six fifty-five minute class perlods and a twenty-five minute lunch period. Work of the seventh grade is so prescribed that no electives are given. $8 B$ pupils are offered one elective, while $8 \mathrm{~A}$ pupils are offered a choice of general mathematics or algebra, and an elective. Doth uivisions of ninth grade have the same cholces as the $8 \mathrm{~A}$ grade. French, Latin, and algebra begun in the eighth grade and spread over one and a half or two years, give the same credit as if begun in the ninth grade and taken in a more concentrated form. 


\section{TABLE I}

TYPICAL PROGRAM OF STUDIES AND PERIODS PER WEEK AT HIGHLAND JUNIOR HIGH SCHOOL FOR THE YEAR 1940-1941.

\begin{tabular}{|c|c|c|c|c|c|c|}
\hline SUBJECNS & $7 B$ & $\begin{array}{c}\text { Peri } \\
7 A \\
\end{array}$ & $\begin{array}{r}\text { ods } \\
8 B \\
\end{array}$ & $\begin{array}{r}\text { per } \\
8 A \\
\end{array}$ & $\begin{array}{c}\text { week } \\
9 \mathrm{~B} \\
\end{array}$ & $9 \mathrm{~A}$ \\
\hline English & 4 & 4 & 5 & 5 & 5 & 5 \\
\hline Social Studies & 4 & 4 & 5 & 5 & 4 & 5 \\
\hline Nathematics * & 5 & 5 & 5 & 5 & 5 & 5 \\
\hline Science & 2 & 2 & 3 & 3 & 4 & 5 \\
\hline Physical Education & 3 & 3 & 3 & 3 & 3 & \\
\hline Health & 2 & 2 & & & & \\
\hline Music & 2 & 2 & 2 & 2 & 1 & 1 \\
\hline Art & 2 & 2 & 2 & & & \\
\hline Guidance & & & & 2 & 2 & \\
\hline Exploratory ** & 5 & 5 & & & & \\
\hline Elective $* * *$ & & & 5 & 5 & 5 & 5 \\
\hline Study Period & & & & & 1 & 5 \\
\hline Iibrary & 1 & 1 & & & & \\
\hline
\end{tabular}

* 8A, 9B, and 9A pupils chose either general mathematics or algebra.

** 7B pupils are offered metal work and clothing. $7 \mathrm{~A}$ pupils are offered printing and woodwork.

*棌 1. Language - Latin or French

2. Home Economics - Foods or Clothing

3. Shops - Metal Work, Woodwork, or Printing

4. Music - Band or Orchestra 
There were twenty-two home room groups during each term of the school year 1940-1941 at Highland Junior High School. Pupils meet in these groups each morning for five minute periods. Here the official attendance is taken, and pupils' grade records are kept. A regular fifty minute class period is given for home room meetings about every other week, alternating with the assembly of the entire school. Pupil composition of home rooms follows no set rule; however, pup1ls of one division of a grade are placed together. Seventh and eighth grades usually meet in the same groups in which they attend classes, while the ninth grade arrangement is made alphabetically. It is the policy at Highland Junior High School for the principal to appoint a teacher-committee to work out definite suggested programs. The use of this material is left to the discretion of each home room teacher. The degree to which the home room period is made worth-while is in the final analysis determined by the teacher-sponsor. In some cases home room is very little more than the means of carrying on the routine administrative work of the school, with left-over time used for study. Also there are some home room periods in which perhaps a highly detalled program is mechanically carried out, while little of real value is obtained by the pupils. In other situations, under the direction of alert, interested, and sympathetic teachers, pupils are receiving 
the soundest kind of education. This is not always accomplished throuch a highly orcanized program, but more often by group sharine of worth-while immediate problems, by pupil participation in all home room activities, and especially by a group feeling of home room spirit to which each individual contributes. One teacher of a home room of boys, of whom many were conduct problems, developed a spirit of pride in the group to which each boy felt responsible. Individual problems became the group's problems. Every type of home room activity was made a group activity. In this kind of situation one of the primary purposes of the home room was met, that is, carryins out an essential part of the guldance program of the school.

The home room teacher is an important factor in helping to orient new pupils. For some of the $7 B$ groups at Fighland Junior Iigh School during 1940-1941, it was possible to have one teacher teach several related subjects and act as home room teacher to the group. This arrangement has proved to be helpful in facilitating adjustments that many pupils meet slowly. Anotrer attempt on the part of the school to help $7 B$ puplis adjust to the new situation is by appointing the visiting teacher as their advisor or conference teacher. She is a famillar person to most 7B students, as she also worlss in the elementary schools in this district. Later in this chapter a description of 
the advisory work of the school will be given.

At the beginning of each september term there are approximately one hundred and fifteen new $9 B$ entries. Some of these pupils are from parochial schools, others are new residents in the city, and about sixty per cent are county residents. These new ninth grade pupils who spend only one year at Highland Junior High School present many problems of articulation. In home rooms, where ninth grade pupils are grouped alphabetically, there is a challenge to the home room teachers to help these new students make easier adjustments. A pupil famillar with the school is appointed to help the new one become famillar with school routine. Articulation has been aided at the Highland Junior High School by the policy followed with pupils entering from the elementary schools in the district. Very soon after promotion of a new class to Highland Junior High School, usually about two weeks, a meeting of the seventh grade teachers, the principal, and the visiting teacher is held to discuss individual pupils. By this time teachers are well enough acquainted with new pupils to recall those who might be discussed. Children's records have been recelved from the previous schools, and home room teachers and perhaps others have perused them. These records contain data pertaining to the child which has been accumulated since his entry in the Loulsville School System. Teachers' grades, 
attendance and tardiness records, health examinations, and group and individual tests, are among the available mater1als. In cases where the visiting teacher has been active, such material as a "family study" or a shorter record of special visits called "special home visit" are contained in each record. Besides this, the sixth grade teacher has written a short statement about each pupil concerning his personality, special ability or inadequacy, which she thinks might be pertinent knowledge for a better adjustment in junior high school. These "personality slips", as they are called, add to the wealth of material avallable to teachers. Before the meeting the visiting teacher lists the names of all puplis whom she believes will be helped by a presentation and interpretation of their cases. In these meetings, it is belleved, teachers' interest in and emotional acceptance of potential problems pave the way for better understanding of individuals. It is very easy for a teacher with the average five classes a day to overlook individuals for whom it is essential to make a right start in the new school situation. These meetings sometimes result in a change in program for the unadjusted or unusual pupil.

Since the advent of junior high schools in the Louisville Public School System, better articulation between the different units, elementary, junior high, and 
senior high schools, has been an administrative objective. Progress has been made in this direction. Perhaps at the time the junior high schools opened, a clearer definition of special functions for each unit, worked out by teacherrepresentatives of each and based upon a comprehensive program for the whole system, would have avoided much inarticulation. However, there are factors which made this impractical. First, at the time the junior high school program was started in Lovisville there were few teachers who were prepared in both experience and education to make a contribution in formulating the special function of each unit. It has necessarily taken time to educate or reeducate teachers in modern educational philosophy, theory, and techniques. Articulation is chiefly effected through teachers. As the contribution each unit must make to the whole becomes clarified and is accepted as sound by the teaching groups, progress is made in articulation between units. Second, there was a period of several-years after the first two junior figh schools opened before similar units were available in all districts. l'his meant that many elementary schools continued to have eight srades, while senior high schools continued to offer their traditional ninth grade courses. As Highland Junior High School. was one of the first, articulation with the senior high schools was greatly hampered during this period, especially 
because of the differences in ninth grade programs. It is suggested that articulation could be facilitated by arranging for teacher visitation between schools, by administrative planning of small district meetings between sixth and seventh grade teachers, and ninth and tenth grade teachers, and by reporting successes and fallures to the previous school. Such reports could furnish the material for re-adjustment and improvements. Clubs at Fighland Junior High School meet before or after school. The membership is open to all pupils, except in such cases where there are grade limitations. New clubs are usually started by several chlidren's requesting permission of the principal to form the elub, and proposing a teacher-sponsor, and then securlng his or her consent to act as sponsor. Some of these groups survive and become permanent organizations, such as the Girls' Service club. The guidance teacher recognized the neea of some type of club for the $9 A$ grade girls. Several girls weire offering their services, to help pupils who were in need of coaching. Others joined this small group, and the services spread to include any worth-while task which pupils or teachers requested. Then the girls asked the principal's permission to organize into a club with the guidance teacher as their sponsor. This organization has held the enthusiasm of its members. 
Other clubs spring up spontaneousiy and die after the initial purpose for which they were formed passes. An example of this is the Dramatic Club, which consists of a group of pupils who wanted to give a play to raise money for British Relief. After the play the club ceased to meet except at irregular intervals. Some clubs are constantly changing. as the members' interests change. The Art Club is an example of this. Every morning before school the art teacher meets pupils who are interested in working on special projects. This group changed its name during the spring to the Landscape Garden Club and changed its focus to beautifying the school yard.

During 1940-1941 the following clubs functioned at Highland Junior High School: Girls' Service Club, Landscape Garden Club, Library Club, Garden Club, Photography Club, Boxing Club, Dramatic Club, Boys' Glee Club, Girls' Glee Club, and First Aid Club.

In developing its club program, Highland Junior High School at one time had regular club periods during school time, and each child was required to attend a meetIng. The present plan seems much more in keeping with sound theory of a junior high school club program. Fretwell has to say on this subject:

Clubs, to be real clubs, have, on the part of their members, so much of idealism, enthusiasm, earnestness, and loyalty that these or- 
ganizations can be neither decreed nor forced. They must be developed. In their development, the pupil's point of view must be the startingpoint; as educators, teachers must so arrange the situation and so guide that the pupil will get from where he is still farther along toward where he ought to be. I7

Band and orchestra, which are offered as elective subjects, are both means of extra-curricular participation. The groups often play for assembly programs and parent-teacher meetings; also, they give programs at elementary schools. During 1940-1941 an operetta was given at Highland Junior High School with these groups and the Glee Clubs as the performers. Approximately seventy-five pupils took part in the actual performances, while the English department assisted with the speaking parts, and the woodwork, metal, art, and elothing departments contributed to the scenery and costuming. These undertakings are valuable because they teach puplls to work together for the success of the production, music accomplishment takes on more meaning for individuals, and the community participates in a school activity. All performances of the operetta were attended by large and enthusiastic audiences of parents and friends. It is desirable that the community be encouraged to come to the school, to see and take

17 Elbert K. Fretwell, Extra-Curricular Activities in Secondary School (Boston: Houghton Miffin Company, I93I), $\mathrm{p} \cdot 274$. 
part in activities. Perhaps making the occasion to which the community is invited a contribution from all school departments, rather than from the music department alone, would prove more beneficial. Interesting projects and materials for displays are being created in day to day class work. Such materials could be used for a school display which might be the nucleus for a school demonstration to the community. Besides giving the community a plcture of what is being done throughout the school, such an exhibit would enable all pupils to make contributions to a school undertaking.

Another means of promoting community participation within the school is through the morning meetings of the Parent-Teachers Association. Five out of the eight meetings of this organization during 1940-1941 were held in the morning, after which parents were encouraged to visit the class rooms and have lunch in the school cafeteria. Mothers who attend the Parent-Teachers meetings st Highland Junior High School approve this plan, as the morning meetings have now been the custom for several years. It is, however, often the mothers who do not attend these meetings who need most to benefit by the contact with the school; then, again, the school needs their participation that it may benefit by a wider community interest. 
The assembly in which the entire school participates offers educational possibilities on a par with other extra-curricular activities. These gatherings are conducted by the student body. Usually the faculty is present with the students as part of the audience. Responsibility for the program rotates among the home room groups working with the home room teacher, the pupils often select the program and help to carry out all necessary details. The value of this type program is the opportunity afforded for the Interplay of initiative, responsibility, and the spirit of teamwork. Besides pupil-executed programs, assemblies are sometimes given over to speakers, moving pictures, and other available attractions. Parents and friends are sometimes invited to special programs; however, the policy has been to keep the assembly a school assembly, serving as an integrating and unifying force for the school.

The school paper, published monthly, has approximately two-thirds of the student body as subscribers. Its purpose is to publish school news and achievements of the school and its individual members, for the benefit of all those who are interested or who may become interested. Its use as an integrating force in the school is comparable to the assembly. The staff is composed of about twenty-five students who have elther volunteered or have been asked to serve by the teacher-sponsor. Teachers often recommend 
pupils to the sponsor. Most of the work of the paper is performed by about fifteen staff members and the sponsor; however, contributions are encouraged from the entire school.

The athletic program of extra-curricular activities is popular with pupils and is an irportant part of the school. Intra-mural games, including soft-ball, basketball, soccer, and touch football are enthusiastically supported. Track meets and tennis and golf tournaments are also features of this program.

A growing custom at Highland Junior High School, which needs special attention, is the regular coaching before and after school. There is no special class period for this. Teachers make their own arrangements. Pupils who have been absent, or who for other reasons need this help, are encouraged to come. These coaching opportunities are being used more and more by pupils who come of their own infitiative when they feel the need.

The fact that students normally have class work six periods each day leaves little time in school for the completion of certain needed drills or remedial work. Teachers arrange to have supervised study in regular instruction periods; however, this does not suffice for all needed skills and enrichments. Consequently pupils in the seventh grade have little need for out of school prepara- 
tion, while the need increases proportionately in the eighth and ninth grades. In a bulletin issued by the Assistant superintendent of Secondary Schools in regard to organization and administration of instruction in the junior high school, the necessity of out of school preparation is mentioned. 18

The Personnel of The Fighland Junior High School

The personnel of the Highland Junior High School for 1940-1941 consisted of a principal, thirty-two class room teachers, including the guidance and health counselors, a librarian, a visiting teacher, an office clerk, an engineer, a fireman, four janitors, a mald, and five lunch room employees. It is the principal who sets the tone in this school by her vision and policy. At the Highland Junior High School her philosophy, ideals, and leadership have been the guices for both the teaching staff and the pupils. Her position as educational leader carries over into the community through such organizations as the ParentTeacher issociation and the Highland Mothers' Club. Her experience includes the principalship of the school since

18 Assistant Superintendent of Secondary School, The Organization and Administration of Instruction in the Junior High Schools of Louisville, Kentucky, pamphlet, 1936. 
Its founding; the principalship of a departmental school consisting of seventh and eighth grades; and a teaching position in the elementary grades. In her training she completes the prescribed work for a Bachelor of Philosophy Degree and a Master of Arts Degree.

It is generally conceded that the realization of junior high school ideals will be largely due to the wholehearted acceptance of the school's philosophy, organization, and administration. With the shift in educational thought from the teacher and what he should do, to the pupil and what he does, has come the realization that the pupil centered school calls for more intelligent, alert, and better trained teachers. Dewey in writing of preparatory training of teachers has this to say:

Education that takes as its standard the improvement of the intellectual attitude and method of students demands more serious preparatory training, for it exacts sympathetic and intelligent insight into the workings of individual minds, and a very wide and flexible command of subject-matter, so as to be able to select and apply just what is needed when $1 \mathrm{t}$ is needed.

The table on Page 30 lists the number of teachers and subjects taught. In some cases teachers conducted classes in other related subjects.

19 John Dewey, How We Think, (Boston: D. C. Heath and Company, 1910$\}, \frac{\text { How }}{\mathrm{p}} \frac{\mathrm{we}}{54}$. Think, (Boston: D. C. 
TABLE II

NUMBER OF TEACHERS AT HIGHIAND

JUNIOR HIGH SCHOOI, 1940-1941, BY SUBJECTS*

\begin{tabular}{|c|c|c|c|}
\hline $\begin{array}{l}\text { Number of } \\
\text { Teachers }\end{array}$ & Sub jects & $\begin{array}{l}\text { Number of } \\
\text { Teachers }\end{array}$ & Subjects \\
\hline 1 & Health & 3 & Science \\
\hline 4 & Nathematics & 1 & Guidance \\
\hline 4 & Social Studies & 1 & Library \\
\hline 2 & visic & 1 & $\begin{array}{l}\text { Latin } \\
\text { French }\end{array}$ \\
\hline 1 & Printing & & \\
\hline 1 & Latin & 1 & $\begin{array}{l}\text { Home Economics } \\
\text { English }\end{array}$ \\
\hline 4 & English & 1 & $\begin{array}{l}\text { Woodwork } \\
\text { Science }\end{array}$ \\
\hline 2 & $\begin{array}{l}\text { Clothing } \\
\text { Physical } \\
\text { Education }\end{array}$ & 1 & $\begin{array}{l}\text { English } \\
\text { Social Studies } \\
\text { French }\end{array}$ \\
\hline $\begin{array}{l}1 \\
1\end{array}$ & $\begin{array}{l}\text { Art } \\
\text { Metal }\end{array}$ & 1 & $\begin{array}{c}\text { Mathematics } \\
\text { Junior Office } \\
\text { Trainine }\end{array}$ \\
\hline
\end{tabular}

* School Directory, Louisville Public School Directory, 1940-1941. 
Twenty-three of the trirty-two teachers are senior college graduates or have the equivalent preparation in their subject, while eight teachers hold Masters Degrees or have the equivalent rating. One teacher has a threo-year training rating. Nine teachers who are at present on the four-year training level are working toward the master's degree. The range of years of experience is from one year to thirty-six years with a median of thirteen years and nine months.

In a democracy the school holds the individual in respect. Ideally the school affords substantial opportunity for personal differences in intellectual and emotional self-realization, while at the same time it imposes upon the Individual a high degree of responsibility. Therefore, a modern democratic school has its focus on the individual. It is a child-centered school which provides services for the whole child. It is clear that this type of school has duties to perform which do not come directly in the category of teaching subjects. These duties we have been accustomed to call "social service". In recognition of this responsibility in the junior high schools of the Louisville Public School System, spectal personnel workers are appointed. At the Highland Junior High School, the guidance counselor, the health counselor, and the visitinf teacher are workers in this field. Each has specific duties 
in her own fleld; however, the work of all three must dovetail. One must complement the other.

The guldance counselor is the coordinator of the guidance program at Highland Junior High School. It is generally conceded that while guidance is in a large sense the paramount function of all education, it is peculiarly the function of the secondary school. Hamrin and Erickson give the following inclusive definition of guidance in the secondary school:

Guidance in the secondary school refers to that aspect of the educational program which is concerned especially with helping the pupil to become adjusted to his present situation and to plan his future in Iine with his interests, ablities, and social needs. The entire school program is complex. Personnel work attempts to simplify it for the individual pupil. It acts as the unifying agency for the individual. In his school career. Guldance ... represents an organized effort on the part of the school, equipped with knowledge of the pupli and information as to opportunities of an educational, a social, and a vocational character to help the individual pupil become adjusted to his present situation in such a way as to promote the greatest development for him and to aid him in planning his future. 20

Home room activities at Highland Junior High

school have been mentioned as having both individual and group guidance values. Under the direction of the guidance counselor, courses in occupational and group gui-

20 Shirley A. Hamrin and Clifford E. Erickson, Guldance in the Secondary Schools, (New York: D. AppletonCentury company, 1939), p. I. 
dance are offered as major attempts in this fleld. The other major part of the guidance counselor's work is concerned with individual and group interviewing. In a paper dealing with guidance practices, the guidance counselor at Highland Junfor High School states:

As guidance counselor at Highland Junior High School, I give my time to the teaching of $8 \mathrm{~A}$ and 9 th grade group guidance classes, to Individual and group conferences, or interviews with pupils, co-workers, or parents, and to administering remedial measures which are necessary. 21

Individual and group conference work with individuals refers to the guidance teacher's work in the capacity of advisor to all 8A, $9 \mathrm{~B}$, and $9 \mathrm{~A}$ classes. During 1940-1941 the principal acted in this capacity to the 7A and $8 B$ classes, and the visiting teacher to $7 B$ classes. The advisor's or conference teacher's work is based on the school's policy of using the "special report card". When a pupil's work is below $c$, the average erade, the teacher of that subject fills out a printed form, the "special report card", giving reasons for the failure with suggestions for Iroprovement. These caräs are turned over to the advisors and are made the basis for interviews with the pupils concerned. The purpose of these interviews

21 Marguerite Reasor, "The Contribution of Psychology to the Guidance Program of a Junlor High School," (unpublished term paper, The University of Loulsv1lle, 1940). 
is to give the student an opportunity to talk over his school problems with an interested person, not associated in his mind with his fallure. Valuable information which leads to better understanding of the child is often obtained during the interviews. Wany of the visiting teacher's home visits develop from these interviews. If Mary telis her advisor that she has been failing in her Latin because she is too tired to get her home assignment and the reason she is tired is that her after school hours are taken up w Ith dancing classes, practicing her music, and attending scout meetings, it is essentially the school's job to investigate Nary's problem further. In this case the visitIng teacher would go into the home to talk over with the mother Nary's burden of activities.

Another special personnel worker at Highland Junior High School is the health counselor. Her program during 1940-1941 included teaching health education approxImately twelve periods a week, testing eyes, weighing and measuring pupils, administering first aid, having individual and group conferences with pupils, teachers and parents, and assisting with physical and dental examinations. The health counselor coordinates all the work in health. Her aim is primarily not to duplicate what can best be done by others, but rather to bring into effective cooperation for the health and welfare of the particular child those measures 
and agencies which her knowledge of the situation indicates as essential. The basis for her work with each individual pupil is the health, dental, and eye examinations given by the school doctor, dentist and nurse, who are employed by the City Health Department. Every pupil has at least one physical examination during the three years he is in junior high school. Dental examinations are given yearly. Eye examinations are made yearly by the health counselor with the telebinocular. These examinations are only an inquiry into a condition. There is a follow-up by the health counselor to maintain or irprove conditions found.

The third worker at Highland Junior High School dealing with personnel work is the visiting teacher. As it is the purpose of this paper to evaluate her work in this area, the general purposes and functions of visiting teacher work will be stated, and her specific work in the Lovisville Public School System and at the Highland Junior High School will be studied.

Concepts of Visiting Teacher Work

Wuch has been written in regard to visiting teacher work, its purposes and functions. Here a few definitions by authorities in the visiting teacher field will be examined.

The chief function of the visiting teacher, or school counselor, is to help the school to study 
and adjust the children who present problems of poor or failing scholarship, of unsatisfactory relationships with companions, of behavior or personality difficulties. Every school has some of these children, often problems to themselves as well as to the school. The aim of the service is to discover children's difficulties before they have become serious and to work out with the school, the home, and social agencies, ways by which the resources of the home and the facilities of the school may be utilized to meet the particular needs of these children. 22

Howard i. Nudd writes concerning the work:

... the school has been turning to the visiting teacher, a comparatively now specialist who has the twofold basic training and experience of a teacher and soclal case worker. The person who performs the intricate task of adjusting the difficulties of problem children cannot be merely a sympathetic visitor between the home and the school, a messenger only, of good will and good tidings from one to the other. Helpful as that is, if it were all that were needed the task would be simple indeed, and doubtless anyone with a kind heart and a pleasing personality would suffice....

... The visiting teacher must be a skilled craftsman who can analyze thoroughly the problems which confront her and can marshall social and educative forces inside and outgide the school for clear and specific purposes.

The visiting teacher is concerned with behavior and personality difficulties. She is an agent in the prevention of delinquency.

22 Jane F. Culbert, "The Visiting Teacher," College domen. and the Social Sciences, (New York: The John Day Company, $\overline{1934} \overline{, \mathrm{pp} .} \overline{71,72 .}$

23 Howard W. Nudd, The Purpose and Scope of Visiting Teacher Work, (New York: Commonwealth Fund, DIvision of Publications, 1930), pp. 4, 5 . 
As has already been indicated the work of a visiting teacher in constantly nipping difficulties of scholarship and behavior in the bud, will ultimately result in lessening retardation, nonattendance, truancy, delinquency, and other problems of a serious character. 24

Dr. Oppenheimer in his book, The Visiting Teacher Movement, gives the following reasons for the establishment of visiting teacher work:

... (I) social conditions and educational requirements demand close relationship between home and school; (2) the increase in the amount of work and in types of activity that teachers must perform curtalls their opportunities of knowing the outside life of their pupils; (3) the present emphasis upon taking into account individual differences and promoting the growth of every child requires some means of knowing and shaping the out-of-school life of the child; (4) the development of modern psychology and social case work provides methods of diagnosis and treatment which are applicable to problems of maladjustment; and (5) the school as an agent of the state in the promotion of public welfare is considered a strategic agency in the fostering of good citizenship and in preventing social maladjustments.

As concelved by leading members of the profession, the work of the visiting teacher should be preventive of more serious trouble. By the preventative element of her work the visiting teacher makes her greatest contribution to the school and to society. A somewhat broader conception of her duties is expressed by Robert $\mathbb{N}$. Bear, pro-

\footnotetext{
$24^{\prime}$ Ibia., p. 12.

25 Julius J. Oppenheimer, The Visiting Teacher Movement, (New York: Joint Committee on Tethods of Preventing Delinquency, 1925), p. 99.
} 
fessor at Dartmouth University, in his book, Soclal Function of Education. Dr. Bear writes:

The visiting teacher having both the training and experience of a social worker and a teacher gives full time to any aspect of pupil management in which contact with the home would be helpful. The specific duties performed vary somewhat in different places but among those frequently given are the handling of chronic tardiness, irregular attendance, major disciplinary problems, cases involving scholarship or health problems, excuses as exemptions from school attendance, visitation of homes and home conditions affecting the development of the pupils. 26

This broader conception more nearly describes the duties of visiting teachers in the Ioulsville Public School System. The trend toward combining visiting teacher and attendance departments seems to be prevaling throughout the country. The Social Work Year Book for 1941 states that visiting teachers in many sections combine their work with attendance work duties. ${ }^{27}$

In conclusion, the following statement is enlightering:

In every school there are individual children who, through undesirable personality traits or because of unfavorable conditions in their home or school life, are failine to reap full benefit

26 Robert $N$. Bear, The Social Function of Education, (New York: The Niacmilian Company, 1937), $\frac{\mathrm{pp}}{10} \frac{\mathrm{D}}{10} \mathrm{I}$, 102.

27 Wilma Walker, "Visiting Teachers," Social Work Year Book 1941, (New York: Russel Sage Foundation, 1941), p. 548. 
from their educational experience.
problems of the visiting teacher. 28

The V1siting Teacher in Louisville and At the Highland Junior High School

The visiting teacher department of the Loulsville Public School System was inaugurated in 1926. With the creation of this department, non-attendance at school was officially recognized as one of the many symptoms of pupil maladjustment, and emphasis was placed upon prevention and removal of the causes, by the study of indiviaual cases.

The administrative policy of this department since its inauguration has been to promote visiting teacher investigation, diagnosis, and treatment of individual pupil problems so that pupils might reap the best possible results from their school experiences and so that the schools might better perform their tasks. There were seventeen visiting teachers working in the white schools in Louisville during the school year 1940-1941. Even though visiting teacher work throughout the entire school system has the same major purposes, the work in aifferent districts reflects the situation of the particular community. Miss

28 Jane F. Culbert, The Visiting Teacher At Work, New York: Commonwealth Fund Division of Publications, IS29), p. 3 . 
Peak in a recent socio-economic study of the Morris School district in Louisville, Kentucky, found visiting teacher work in this school concerned with many problems caused. by overcrowded housing conditions, low economic status of families, and a high rate of moblitty. 29 The Highland Junior High School district has a comparatively high rental area for dwellings, a majority of home owners, and influences which tend toward organizetion. Here visiting teacher work is concerned with causes of a different nature. Perhaps for a better understanding of the fundamental causes of maladjustment, no matter in what type community the pupil Iives, it is best to define basic personalIty needs of all individuals. These are forcefully given by Prescott, in the book Emotion and The Educative Process:

The needs of developing children fall naturally into three categories representing three major aspects of the Iffe of a person. These categories of need can be called: (1) physiological, when describing needs that spring primarily out of structure and dynamic biochemical equilibria; (2) social or status needs, when describing the relationships that are essential to establish with other persons in our culture; and (3) ego or integrative needs, when describing needs for experience and for the organization and symbolization of experience through which the individual will discover his role in life and learn to play it in such an effective manner as to develop a sense of wortby selfhood....

29 Naomi Peak, "A Study of The George W. Morris School and Community with Emphasis Upon The Personnel Work of The School" (Unpublished Master's Thesis, The University of Louisville, Louisville, Kentucky, 1941), p. 160 . 
Any situation which does violence to the personality needs with which the child is preoccupied at the time can evoke unwholesome behavior. 30

It can be seen from the description of these needs that there are many conditions which upset the orderIy development of a child and cause him to protest or compensate the frustration by showing some form of maladjustment by his behavior. These conditions may develop through the home and the school as well as through all other contacts the cilid might have. It is obvious that there are pupils at the Highland Junior High School, as well as in all other schools, who will at some time or another be affected to a greater or lesser degree. The rejected child; that is, he who is denied the affection of his family group, the physically unusual child, he who is very large, or very fat, who has skin blemished, etc.; the mentally deficient child, he who is limited in competing with others in his group; the child whose desires and ambitions are greater than his ablitty, or whose parents' strivings for social status are exerting pressures on him; the child whose rate of motivation is not in keeping with those of his grcup; the child who is over-protected, or used by his parents primarily for the release of their own emotions; the child

30 Daniel A. Prescott, Emotion and The Educative Process, (Washington, D. C.: American Council on Education, 1938), pp. 127, 128 . 
who is physically below par; the over-stimulated child, who because of the modern tempo of his life has little time for quiet and contemplation; present some of the problems with which the visiting teacher at the Highland Junior High School is concerned.

The table on Page 43 shows the number and percent of cases for which home visits were made by the visiting teacher at the Highland Junior High School for the school year 1940-1941. This record was kept by the cause of referral and not by the final diagnosis of the case. It is a record kept for statistical purposes, and it merely shows the type of work which she handies at this school. 
TABLE III.

NUMBER OF CASES BY CAUSES OF REFERRAL FOR WHICH

HOME VISITS WERE MADE BY THE VISITING TEACHER

AT THE HIGHLAND JUNIOR HIGH SCHOOL

FOR THE SCHOOI YEAR 1940-1941

\begin{tabular}{|c|c|c|}
\hline Cause of Referral & $\begin{array}{c}\text { Number } \\
\text { of Cases }\end{array}$ & Percent \\
\hline Scholarship & 253 & 25.42 \\
\hline Census & 252 & 25.32 \\
\hline Attendance & 155 & 15.57 \\
\hline Behavior & 120 & 12.06 \\
\hline Tardiness & 53 & 5.32 \\
\hline Adjustment & 43 & 4.32 \\
\hline Others & 42 & $4 \cdot 22$ \\
\hline Guidance & 32 & 3.21 \\
\hline Other social agencies & 14 & 1.40 \\
\hline Health & 12 & $1 \cdot 20$ \\
\hline Investigation for free lunch & 8 & 0.80 \\
\hline Investigation for Christmas Baskets & 4 & 0.40 \\
\hline Investigation for free carfare & 3 & 0.30 \\
\hline TOTAL & 995 & 99.54 \\
\hline
\end{tabular}


As will be noted, the visiting teacher's work is not concerned only with duties relative to case work. The work includes all manner of home visits and pupil contacts that the principal might feel can best be handled by the visiting teacher. Investigation for free lunch, free carfare, and other physical needs which the school might supply are included. All types of census work necessary to maintain a continual and changing school census in keeping with the State law are among her duties. Table III shows that 25.42 percent of the cases for which home visits were made were for the school census. This percentage might seem comparatively large in proportion to the other cases. The amount of time necessary to make visits of this type, however, is very little, as visits consist of short inquiries about members of the household to determine addresses of census age children, in accordance with the Kentucky state requirements. Time for each of these types of visits must be given in relation to their importance. An indisputable fact is that as that member of the school appointed to assist the individual pupil in his adjustment and the school in accomplishing its goals with all individuals, the visiting teacher's major efforts must be to prevent social failure and waste. A study of Table III indicates that the overwhelming percentage of visits were concerned 
with this major purpose of visiting teacher work. The principal has encouraged initiative and freedom in the visiting teacher service at Highland Junior High School. The visiting teacher has free access to teachers, pup1ls, and class rooms, and she holds Informal conferences with the principal. During this time new cases are given her and referrals from other sources are discussed. The guidance counselor and health counselor refer cases by informal conferences. Often all three workers and the principal talk over referrals. Health problems are always referred first to the health counselor who in turn calls in the visiting teacher when she believes this service is necessary. Teachers' referrals are made to the visiting teacher either by planned or casual conference usually during their free periods, Iunch time, before and after school, or by written "special report cards" for $7 B$ pupils. The latter form is part of the advisory system previously discussed in this chapter. Advisors, whether the principal, guidance counselor, or visiting teacher, upon receiving special report cards for the first time, usually confer with pupils, and only those cases which seem necessary are investigated further by the visiting teacher. The decision for visiting teacher service is made by the advisors.

The investigation of attendance and tardiness 
cases is usualiy left to the discretion of the visiting teacher, except for unusual situations when teachers or the principal request investigations. It is not unusual for a referral to come from several sources at once. Unsatisfactory conduct, poor scholarship, irregular attendance, poor health, any or all might become apparent at one time. One might be causing the other, or all might be symptoms of some other condition in the child's life. In such cases it is often difficult to know the exact source of referral.

Sometimes cases are referred to the visiting teacher by parents. In such cases it is apparent that pupils have not been considered problems at school because they conform to the accepted standards of the school, which may not always be a measure for the well adjusted personality. E. K. wickman, in his study of teachers' attitudes toward children's behavior states:

The purely personal problems of children which do not frustrate the immediate purposes of teachers or their standards of good conduct are not regarded by them as symptomatic of significant malad jus tment. 31

In other cases referred by parents to the visit-

31 E. K. Wickman, Chilaren's Behavior and Teacher's Attitudes, (New York: The Commonwealth Fund, Division of Publications, 1928), p. 11 . 
Ing teacher the problem may lie in the parent-child relationship, and outside of this area the child may show normal behavior, or again the problem may be with the parent only, elther imaginary or real.

At the Highland Junior High School the visiting teacher's time is employed in conferences and interviews with pupils, teachers, and parents, in home visiting, in census work, in communicating with other social agencies, and in studying all possible information and applying remedial measures.

The visiting teacher spends three days a week at the Highland Junior High School. On the other two dajs of the school week she works in four elementary schools, three of which are "feeder" schools to this junior high school. Having both elementary and junior high schools in the same district has proved to be a satisfactory arrengement for several reasons. First, it is economical, as often children from the same family attending different units need visiting teacher services. Second, it is possible to establish better rapport between parents and pupils, if there Is one visitor who is not too closely connected with the policy of any one school, but who is identified with all the schools in the district. Such a person's interest is in the child himself. A third reason is given in the Soclal Work Year Book for 1937, which states that the best 
results are secured when the visiting teacher is part of one school or a small group of schools, because this allows her to become familiar with a neighborhood and to be 1dentified with it. 32

The school, the community, and the home are the three major influences in a child's life. In this study of the Highland Junior High School and its district, two of these influences have been considered. The third major influence, the home, w11l be studied later in this thesis. In regard to the functioning of these influences in educating the child, Hamrin and Erickson say:

... the education of children is a cooperative responsibility of school, home, community.... Effective education is dependent upon the extent to whick these organizations marshal their resources for cooperative purposes. 33

32 Carmelite Janvier, "Visiting Teachers," Social Work Year Book 1937, (New York: Russel Sa E Foundation, 1937), p. $52 \overline{8}$.

33 Fiamrin and Erickson, op. cit., p. 217. 
THE SLIECTION OF THE GROUPS 


\section{THE SELECTION OF THE GROUPS}

One of the purposes of this thesis is to evaluate visiting teacher work. The evaluation is based principally upon a comparative study of sixty visiting teacher cases, called the visiting teacher's group, and sixty cases representing a cross section of the school, called the normal group. In this chapter the process of selectIng each group will be shown.

The Selection of the Visiting Teacher Group

The selection of the visiting teacher cases was made with the purpose of including all cases regardless of case outcomes or length of time they were carried, in which visiting teacher participation was sufficient to be considered in studying results. The visiting teacher group includes all cases at the Highland Junior High School for which the visiting teacher offered the following services during the school year 1940-1941: making one or more home visits, using case work methods of treatment, and writing or adding to a previously written case history. If, however, a case met these requirements but had only an initial home visit recorded with no further visiting teacher treatment either with the pupil or with the home or school in 
regard to the pupll, it was eliminated from the study. This was done because with cases of this type the degree of visiting teacher participation was not sufficient to justify drawing conclusions from outcomes.

It must be pointed out that the sixty cases for which visiting teacher service was given do not represent all pupils who manifested scholarship difficulties, deviations in behavior patterns, or other symptoms which characterize maladjusted pupils. Other cases were carried by the principal, guidance counselor, and health counselor.

The visiting teacher cases considered in this study represent varying degrees of visiting teacher participation. With some cases home investigations only were made, while with others the visiting teacher assumed the largest share of responsibility in all phases of the investigation, diagnosis, and treatment. The necessity of cholce in cases as in the amount of service given per case is evident. This is determined sometimes by circumstances surrounding the case, sometimes by the principal or by other personnel workers in the school, and sometimes by the visiting teacher herself. Gladys Hall, in discussing this topic, says:

It is possible that our notion has changed somewhat about the amount of case work we ourselves should carry. ... With the acquisition of newer concepts of case work, visiting teachers realize that there are some cases which cannot be treated by them nor by any case worker, others which should 
not be treated by them but referred elsewhere if possible, and some which can be carried largely by the teacher or parent with only advisory service from the visiting teacher, in addition to the group for whom they must assume the largest share of responsibility. The referral to others will depend largely upon the resources of the community, whether the visiting teacher is working with the child guidance clinic or as a single worker, on the wishes of the school administrator under whom she is working directly, the activities of other school departments, and her own qualifications as well as other duties expected of her. I

The sixty visiting teacher cases considered in this study were referred by the principal, guldance counselor, health counselor, class room teachers, or parents, or the visiting teacher initiated the investigation. In Table IV is shown the source of referral and the number and per cent referred from each source. As each school year is a separate unit, and this study is concerned with case work during the school year 1940-1941, the source of referrals tabulated are of that year.

1 Gladys E. Hall, "Changing Concepts in Visiting Teacher Work," Readings in Social Case Work 1920-1938(Fern Lowry, editor; New York: Columbia University Press, 1939), p. 511 . 
TABLE IV

SCOURCES OF REFERRALS OF THE SIXTY VISITING TEACHER

CASES AT THE HIGHLAHD JUNIOR HIGH SCHOOL

FOR THE YEAR 1940-1941

\begin{tabular}{lcc}
\hline Source of Referral & $\begin{array}{c}\text { Number } \\
\text { of Cases }\end{array}$ & $\begin{array}{c}\text { Per Cent } \\
\text { of Cases }\end{array}$ \\
\hline Guidance Counselor & 18 & 30.00 \\
Visiting Teacher & 14 & 23.33 \\
Principal & 13 & 21.67 \\
Health Counselor & 9 & 15.00 \\
Classroom Teachers & 3 & 5.00 \\
Parents & 3 & 5.00 \\
& 60 & 100.00 \\
\hline
\end{tabular}

Table IV shows that of the sixty visiting teacher cases, the principal referred thirteen cases or 21.67 per cent, classroom teachers referred three cases or 5 per cent, the guidance counselor referred eighteen cases or 30 per cent, the health counselor nine cases or 15 per cent, and the visiting teacher initiated the investigation for fourteen cases or 23.33 per cent. Parents requested the visiting teacher's services for three cases or 5 per cent. The small percentage of cases referred by classroom teachers is due to the fact that the usual procedure at Highland Junior High School is for teachers to refer cases to the advisor. In turn the advisors refer cases which they believe in need of 
visiting teacher service. As the principal, the guidance teacher, and the visiting teacher were the advisors, referrals from these sources were the largest.

The Selection of the Normal Group

The selection of the normal group was made by taking a sample of the entire school population. The collecting of data for the whole student body in the many different areas which are compared in this study would constitute a major task. As the use of sampling is an accepted policy in educational research, it seemed advisable to employ this process in selecting a group to be used as a basis for comparative purposes. The selection of this sample or normal group was obtained as of May 31, 1941. School membership is never stat1c. There is continual change in number and in the individuals who make up the school's population. The average dally membership of the Highland Junior High School for 1940-1941 was 702. The day the sample was taken the membership was 700 .

For the purpose of this study pupils living at the German Protestant Orphanage were excluded because their home situation is not comparable to that of the visiting teacher's group. None of these pupils was included in the visiting teacher's group studied. There were thirty-four such pupils in membership on the day the sample was taken. 
This group represented only 4.8 per cent of the entire school population. Thus the membership considered numbered 666 . The sample selected must be enough like the total population to insure the fact that any statistical measure computed from it will be close enough to the same measure computed from the total population to serve the purpose of the investigation.

In order to assure a representative sample the total school population was tabulated in four major areas, and the occurrences in these areas were computed. The sample was then taken in proportion to the whole within each area. Economic status was used as the basic area. Others were grade, sex, and intelligent quotient.

The modern public opinion polls, notably the American Institute of Public Opinion and Fortune Survey, are current outstanding examples of the use of population sampling. Although these surveys differ from each other in minor points, in the main the method used relies upon the proportionate representation of all the major groups within the population to be sampled. ${ }^{3}$ These surveys placed the emphasis on the character of the cross section rather than on

2 James E. Wert, Educational Statistics (New York: McGraw-Hill Book Company, Inc., 1938), pp. 136-37.

3 George Gallup and Sol Forbes Rae, The Pulse of Democracy (New York: Simon and Schuster, 1940), pp. 72-73. 
the size. The Literary Digest Poll which showed a nineteen point error in predicting the presidential election of 1936 was based on a more than adequate number of samples, but the neglect to insure a proportionate sample of each class In the whole voting public was one of the major reasons for the large error. 4

With the use of the method of proportionate sampling, it was found that the sixty cases would be an adequate number for a study of this problem. Palmer O. Johnson, Professor of Education at the University of Minnesota, sugeested the formula on the following page to determine whether the number would be adequate and representative. He suggested that some measurable character such as $I . Q$. be used to show that there is no significant difference between the character of the sample and the total school population. The formula is as follows:

4 op. cit. pp. 74,75. 


$$
\frac{\bar{x}_{n}-\bar{x}_{N}}{\frac{N-n}{N} \cdot \frac{\sigma^{2}}{n}}
$$

$\mathbb{N}=$ population $=666$

$\mathrm{n}=$ sample $=60$

$\bar{x}_{\mathrm{n}}=$ mean $I \cdot Q$. of the sample $(60)=107.666$

$\bar{X}_{N}=$ mean $I \cdot Q$. of the population $(666)=108.586$

$\sigma=$ standard deviation of the sample $=\sqrt{25.406}$

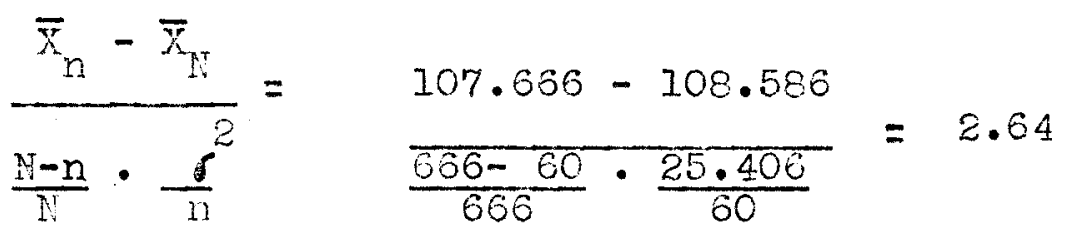

Dr. Johnson says that if this ratio does not exceed three (3), this fact can be presented as evidence that the sample is adequate for estimating the population value. Since the ratio in the present problem is 2.64 , or less than three, it is assumed that the sixty cases chosen by proportionate sampling are adequate. ${ }^{5}$

These steps were taken in selecting the sample for this study: (1) grouping the school population consisting of 666 pupils in economic status groups, (2) tabulating the results in each economic group according to sex

5 Palmer 0. Johnson, Professor of Education, University of Minnesota (Letter March 13, 1942). 
and grade, (3) finding the per cent of the school population in each economic group according to sex and grade, (4) finding the number of sample cases to be selected in each group according to sex and grade by taking the same per cent as occurred in the school population in these areas, (5) setting up a check sheet for each grade showing I.Q.'s, sex, and economic groups, (6) placing each member of the school population on this sheet according to his respective position, (7) selecting the sample from this sheet by using the same per cent as nearly as possible in economic levels, grade, and sox as are present in the total population, and picking the sample cases by considering the range and frequency of I. Q.'s. These steps will be described in more detall.

The grouping of the pupils according to economic status was made by the principal and the visiting teacher. Both persons have knowledge of the economic standards maintained by most of the families in school, as both are in a position to acquire a variety of facts relative to this area. In determining economic ratings, five group levels were set up, "high" Group I, "medium high" Group II, "medium" Group III, "medium low" Group IV, and "Iow" Group V. These levels have meaning only in relation to the situation in this school. Residence and parents' occupations were considered in placing pupils in the different economic levels. Also other per- 
tinent information shown in school records was used. In the "high" economic level, Group I, were placed pupils livIng in large homes or expensive apartment houses. Parents of children in this group are executives of large businesses, bankers, professional men, and army officers of the rank of captain or higher. In the "medium high" economic level, Group II, were placed pupils living in homes and apartments somewhat above the average for the district, but not up to the standard of Group I. Parents of these children are ensaged in many of the same occupations as those in Group. I, while some are merchants, business representatives, and contractors. The "medium" economic level, Group III, consists of pupils living in average homes in the district. Parents In this group are small business proprietors, assistants in Eovernmental employment, selling agents and clerical workers. However, many of the occupations occurring in Group II are also found in this one. The "medium low" economic level, Group IV, consists of pupils living on the more modest streets in the district. Parents of children in this group are skilled workers such as mechanics, transportation tradesmen, firemen, policemen and postmen. However, in this group also will be found parents' occupations represented In Group III. The "low" economic level, Group V, consists of pupils living in cramped, small homes in the low rent areas, or living with other families because of the wage 
earners' unemployment. Parents of this group are delivery men, watchmen, and laborers. It can be easily seen from the description of each level, that lines were not clearly drawn in each group. It was felt that rigid grouping would exclude many factors which made up the entire situation for each individual. The subjective opinion of the principal and the visiting teacher in placing the school population in these groups seemed adequate for the purpose of this study. A tabulation of results of the economic levels (See Tables V and VI) shows there are seventeen boys and eight girls, a total of twenty-five, in Group I; eightyseven boys and one hundred and forty-five girls, a total of two hundred and thirty-two, in Group II; one hundred and fifty-eight boys and one hundred and sixty girls, a total of three hundred and eighteen, in Group III; thirty-six boys and forty-three girls, a total of seventy-nine, in Group IV; and four boys and elght girls, a total of twelve, in Group $V$. The eroups represent approximately 3 per cent, 35 per cent, 48 per cent, 12 per cent; and 2 per cent respectively, of the school population. This means that for every hundred students in the population, the ratio for the sample is three from Group I, thirty-five from Group II, fortyelght from Group III, twelve from Group IV, and two from Group $V$. The number of sample pupils to be used in each group is obtained by taking three fifths or sixty per cent. 
The nearest approximate whole number was taken as follows: two from Group I, twenty-one from Group II, twenty-nine from Group III, seven from Group IV, and one from Group V. Table $V$ shows the distribution by grade and sex of the membership with the number of sample pupils taken from each group. 
TABLE V

DISTRIBUTION OF BOYS' NEMBERSHIP OF THE HIGFILAND JUNIOR

IIIGH SCHOOL, MAY 31, 1941, ACCORDING TO ECONONIC

GROUP AND GRADE, WITH NUMBER ALD PER CENT

OF SAMPLES FRON EACH

\begin{tabular}{|c|c|c|c|c|c|}
\hline $\begin{array}{l}\text { Economic } \\
\text { Group }\end{array}$ & \multirow[t]{2}{*}{ Grade } & \multicolumn{2}{|c|}{ Nembership } & \multicolumn{2}{|c|}{ Samples } \\
\hline & & & & & \\
\hline$I$ & $\begin{array}{c}7 \\
8 \\
9 \\
\text { Total } \\
\end{array}$ & $\begin{array}{r}2 \\
2 \\
13 \\
17 \\
\end{array}$ & $\begin{array}{r}.30 \\
.30 \\
1.95 \\
2.55 \\
\end{array}$ & $\begin{array}{l}0 \\
0 \\
1 \\
\end{array}$ & $\begin{array}{l}0 \\
0 \\
1.6 \\
1.5 \\
\end{array}$ \\
\hline II & $\begin{array}{c}7 \\
8 \\
9 \\
\text { Total } \\
\end{array}$ & $\begin{array}{r}33 \\
18 \\
35 \\
87 \\
\end{array}$ & $\begin{array}{r}4.9 \\
2.7 \\
5.4 \\
13.0 \\
\end{array}$ & $\begin{array}{l}3 \\
2 \\
3 \\
8 \\
\end{array}$ & $\begin{array}{l}5 . \\
3.3 \\
5 . \\
13.3 \\
\end{array}$ \\
\hline III & $\begin{array}{c}7 \\
8 \\
9 \\
\text { Total } \\
\end{array}$ & $\begin{array}{r}47 \\
48 \\
63 \\
158 \\
\end{array}$ & $\begin{array}{r}7.1 \\
7.2 \\
8.4 \\
23.7 \\
\end{array}$ & $\begin{array}{r}4 \\
4 \\
6 \\
14 \\
\end{array}$ & $\begin{array}{r}6.6 \\
6.6 \\
10 . \\
23.2 \\
\end{array}$ \\
\hline IV & $\begin{array}{c}7 \\
8 \\
9 \\
\text { Total } \\
\end{array}$ & $\begin{array}{r}8 \\
8 \\
20 \\
36 \\
\end{array}$ & $\begin{array}{l}1.2 \\
1.2 \\
3.0 \\
5.4 \\
\end{array}$ & $\begin{array}{l}1 \\
0 \\
\frac{2}{3} \\
\end{array}$ & $\begin{array}{l}1.6 \\
0 \\
3.3 \\
4.9 \\
\end{array}$ \\
\hline V & $\begin{array}{c}7 \\
8 \\
9 \\
\text { Total }\end{array}$ & $\begin{array}{l}2 \\
0 \\
2 \\
4 \\
\end{array}$ & $\begin{array}{r}.30 \\
.30 \\
.60\end{array}$ & $\begin{array}{l}0 \\
0 \\
0 \\
0\end{array}$ & $\begin{array}{l}0 \\
0 \\
0 \\
0\end{array}$ \\
\hline
\end{tabular}


TABIE VI

DISTRIBUTION OF GIRIS' MEMBERSFIP OF TFE HIGHLAND JUNIOR IIGH SCHOOI, MAY 31, 1941, ACCOREING TO ECONOMIC GROUP AND GRADE, WITH NUMBER AND PER CENT OF SAMPLES FROM EACH

\begin{tabular}{|c|c|c|c|c|c|}
\hline \multirow{2}{*}{$\begin{array}{l}\text { Economic } \\
\text { Group }\end{array}$} & \multirow[t]{2}{*}{ Grace } & \multicolumn{2}{|c|}{ Membership } & \multicolumn{2}{|c|}{ Samples } \\
\hline & & No. & Per Cent & No. & Per Cent \\
\hline$I$ & $\begin{array}{c}7 \\
8 \\
9 \\
\text { Iotal } \\
\end{array}$ & $\begin{array}{l}3 \\
4 \\
\frac{1}{3} \\
\end{array}$ & $\begin{array}{r}.5 \\
.6 \\
.1 \\
1.2 \\
\end{array}$ & $\begin{array}{l}0 \\
1 \\
0 \\
\end{array}$ & $\begin{array}{l}0 \\
1.66 \\
0 \\
1.66\end{array}$ \\
\hline II & $\begin{array}{c}7 \\
8 \\
9 \\
\text { Total } \\
\end{array}$ & $\begin{array}{r}35 \\
41 \\
69 \\
145 \\
\end{array}$ & $\begin{array}{r}5.2 \\
6.5 \\
10.0 \\
21.7 \\
\end{array}$ & $\begin{array}{r}3 \\
4 \\
6 \\
13 \\
\end{array}$ & $\begin{array}{r}5.0 \\
6.6 \\
10.0 \\
21.6 \\
\end{array}$ \\
\hline III & $\begin{array}{c}7 \\
8 \\
9 \\
\text { Total } \\
\end{array}$ & $\begin{array}{r}40 \\
42 \\
78 \\
160 \\
\end{array}$ & $\begin{array}{r}6.0 \\
6.3 \\
11.7 \\
24.0 \\
\end{array}$ & $\begin{array}{r}4 \\
4 \\
7 \\
15 \\
\end{array}$ & $\begin{array}{r}6.6 \\
6.6 \\
11.8 \\
25.2\end{array}$ \\
\hline IV & $\begin{array}{c}7 \\
8 \\
9 \\
\text { Total } \\
\end{array}$ & $\begin{array}{l}11 \\
13 \\
19 \\
43 \\
\end{array}$ & $\begin{array}{l}1.6 \\
2.0 \\
2.8 \\
6.4 \\
\end{array}$ & $\begin{array}{l}1 \\
1 \\
\frac{2}{4}\end{array}$ & $\begin{array}{r}1.6 \\
1.6 \\
3.4 \\
6.6 \\
\end{array}$ \\
\hline $\mathrm{V}$ & $\begin{array}{c}7 \\
8 \\
9 \\
\text { Total } \\
\end{array}$ & $\begin{array}{l}7 \\
0 \\
1 \\
8\end{array}$ & $\begin{array}{l}1.1 \\
0.1 \\
0.1 \\
1.3\end{array}$ & $\begin{array}{l}1 \\
0 \\
0 \\
1\end{array}$ & $\begin{array}{l}1.66 \\
0.0 \\
0.0 \\
1.66 \\
\end{array}$ \\
\hline
\end{tabular}


Tables $V$ and VI show that in Economic Group I in the school membership there were two boys in the seventh grade, two boys in the eighth grade, and thirteen boys in the ninth frade, a total of seventeen boys. The girls in Economic Group I were divided as follows: three in the seventh grade, four in the eighth grade, and one in the ninth grade. From this distribution in Group I two sample pupils were to be chosen. It seemed best to pick one of each sex; then, as there were thirteen boys in the school membership of the ninth grade, Group I, the boy chosen was from this grade. As the greatest number of girls in school membership in Group I was in the eighth grade, the sample girl in this Group was taken from this grade. In choosing the sample pupils proportionately from the other economic groups, the same care was taken to assure, as far as possible, a proportionate selection of sample pupils within each grade and by sex.

A "check-sheet" was set up for each Erade showing the range of I. Q.'s, grades, sex, and economic levels. Each pupil was placed on this sheet according to his respective position. The range and frequency of I. Q.'s were then considered in picking the sixty samples according to the other determined areas.

The sample cases selected make up the normal group which is compared in the following chapter with the visiting teacher group. 
A PRESENTATION OF THE DATA 
CHAPTER III

\section{A PRESENTATION OF THE DATA}

The study of the Highland Junior High School and the community in which it is locatea, which was given in Chapter I, presents an environmental background which affects every pupil in the school. In visiting teacher case work, these factors help make up the total situation in each case. The purpose of this stuay is to evaluate visiting teacher case work in this school for the year 19401941. The evaluation is based upon a comparative study of sixty visiting teacher cases, called the visiting teacher's group, and sixty cases representing the normal of the school, called the normal group. The selection of these groups was discussed in Chapter II. Wherever possible in the comparisons to be made, results which are indicative of visiting teacher service will be brought out.

In this chapter the two groups are compared in age, intelligent quotients, grade and sex, in school attendance, in teachers' grades, in health, in extra curricular activities. It seemed practical in this study to compare as many different areas of these two groups as possible. Many of these do not have characteristics which can be influenced by the visiting teacher. Nevertheless, certain valuable conclusions which are especially pertinent to the improvement of visiting teacher work can be drawn from them. 
Such questions as the following will be considered: Is the visiting teacher's group less bright than the children with whom they compete, the normal group? Is the visiting teacher's group older or younger in comparison with the age group with whom it is placed? Are the physical qualifications of the visiting teacher's group on a par with those of the normal group? Are home conditions more or less favorable in the visiting teacher's group than in the normal group? The answers to these questions point the way for more emphasis on certain basic problems by the visiting teacher at the Highland Junior High School.

It was felt that an estinate of results of all types of problems presented by the sixty visiting teacher cases would be desirable for the purposes of this study. For an estimate of this kind the classroom teachers were asked to give their opinions of outcomes of cases by answering a questionnaire for each case. The final topic in this chapter will take up the results of these questionnalres.

A Comparison of the Normal Group With the Visiting Teacher Group

It seems advisable to show a comparison of the distribution of cases by number and per cent, by average age, by intelligent quotient, including medians and ranges, by grade and sex of the normal group. with the visiting teach- 
er group. The first reason this corparison is made is to determine if the visiting teacher recelves cases proportionately by grades and sex throuchout the school. If the visiting teacher cases are proportionately distributed by grade, it seems right to assume it is accidental. It is obvious to those who are concerned with individuals ana their problems in a school situation that sometimes entire classes, either large or small, do not have individuals who are in need of visiting teacher services, while other classes may have a proportionately large number. It is not the purpose of this study to determine why this is true. Wuch research on this question is necessary before any conclusions can be drawn. The results of the comparison of the visiting teacher group and the normal group by sex will indicate whether there are proportionately more boys than girls who are visiting teacher problems. The second reason this comparison is made is to determine how the pupils of the visiting teacher group compare in age and I. Q. with their fellow pupils. Table VII on Pages 67 and 68 shows these comparisons. 
TABLE VII

CONPARISON OF PUPIIS OF THE NORMAL GROUP WITF THOSE

OF TIE VISITING TEACHER GROUP AT THE HIGHLAND

JUIOR FIIGH SCHOOL AS THEY ARE DISTRIBUTED IN

NUMBER, PER CENT, AVERAGE AGE, INTEILIGENT

QUOTIENT NEDIANS AND RANGES, BY GRADES

AND SLX, FOR THE YEAR 1940-1941

\begin{tabular}{|c|c|c|c|c|c|c|c|}
\hline Grade & Sex & $\begin{array}{l}\quad \text { Numk } \\
\text { Normal } \\
\text { Group }\end{array}$ & $\begin{array}{l}\mathrm{V} \cdot \mathrm{T} \cdot * * * \\
\text { Group }\end{array}$ & $\begin{array}{l}\quad \text { Per C } \\
\text { Normal } \\
\text { Group }\end{array}$ & $\begin{array}{l}\text { ent } \\
\mathrm{V} \cdot \mathrm{T} \cdot * * * * \\
\text { Group }\end{array}$ & $\begin{array}{l}\text { Average } \\
\text { Normal } \\
\text { Group }\end{array}$ & $\begin{array}{l}\text { Age* } \\
\text { V.T.*** } \\
\text { Group }\end{array}$ \\
\hline \multirow[t]{2}{*}{7 th } & Boys & 8 & 16 & 13.3 & 26.7 & $12-10$ & $12-5$ \\
\hline & Girls & 9 & 7 & 15.0 & 11.7 & 13 & $13-4$ \\
\hline \multirow[t]{2}{*}{8 th } & Boys & 6 & 9 & 10.0 & 15.0 & $14-5$ & $13-10$ \\
\hline & Girls & 10 & 2 & 16.7 & 3.3 & $13-8$ & $13-6$ \\
\hline \multirow[t]{3}{*}{9 th } & Boys & 12 & 17 & 20.0 & 28.3 & 15 & $15-2$ \\
\hline & Girls & 15 & 9 & 25.0 & 15.0 & $14-9$ & 15 \\
\hline & Totals & 60 & 60 & 100.0 & 100.0 & $14-2$ & $14-3$ \\
\hline
\end{tabular}

* Age in years and months computed as of liay 31, 1941. * Visiting Teacher Group. 


\section{TABLE VII (CONTINUED)}

COMPAPISON OF PUPIIS OF THE NORHAI GROUP WITH THOSE

OF THE VISITING TEACHER GKOUP AT THE IHIGHLAND

JUNIOR HIGH SCHOOL AS THEY AFE DISTRIEUTED IN

NUMBER, PER CENT, AVERAGE AGE, INTELIIGENT QUOTIENT MEDIANS AND RANGES, BY GRADES

AND SEX, FOR TEE YEAR 1940-194I

\begin{tabular}{|c|c|c|c|c|c|}
\hline Grade & Sex & $\begin{array}{l}\text { Nedian } \\
\text { Normal } \\
\text { Group }\end{array}$ & $\begin{array}{l}\text { I.Q.' } \\
\text { V.T. } * 3 \% \\
\text { Group }\end{array}$ & $\begin{array}{l}\text { Range of } \\
\text { Normal } \\
\text { Group }\end{array}$ & $\begin{array}{l}I \cdot Q \cdot ' s \\
V \cdot T \cdot * * * \\
\text { Grour, }\end{array}$ \\
\hline \multirow{2}{*}{$7 \operatorname{th}$} & Boys & 105 & 109 & $95-121$ & $95-128$ \\
\hline & Girls & 107 & 113 & $98-126$ & $84-126$ \\
\hline \multirow{2}{*}{ sth } & Boys & 107.5 & 103.5 & $93-116$ & $94-116$ \\
\hline & Girls & 108.5 & 111 & $97-116$ & 111 \\
\hline \multirow{3}{*}{9 th } & Boys & 107.5 & 100 & $93-113$ & $88-134$ \\
\hline & Girls & 107 & 115 & $87-128$ & $84-128$ \\
\hline & Totals & 107 & 108.5 & $87-128$ & $84-134$ \\
\hline
\end{tabular}

Nean I.Q. Visiting Teacher Growp 107.893

Nean I.Q. Nomal Group

107.666

** Visiting Teacher Group. 
Table VII shows that the number and per cent of the visiting teacher group of cases by grades and sex do not coincide with those of the normal group. In the seventh grade there are twice as many boys in the visiting teacher group as there are in the normal sroup, while the difference is smallest, only two or 3.3 per cent, between the two groups of the seventh grade girls. In the eighth grade the visiting teacher group contains three, or 6 per cent more boys than the normal group, while the normal group contains elght, or 13.4 per cent more girls than the visiting teacher group. The ninth grade distribution shows five, or 8.3 per cent more boys in the visiting teacher group than in the normal group, while the normal group has six, or 10 per cent more girls than the visiting teacher group. In the age comparisons in Table VI the two groups correspond more closely, the greatest difference being in the eighth grade boys where the averace ace of the normal group is seven months older than the visiting teacher group.

In order to prove statistically that there is no significance in the difference between the mean I.Q.'s of the groups, 107.893 for the visiting teacher group, and 107.666 for the normal group, the formula for the signifi- 
cance of difference was applied. ${ }^{1}$ The result was an answer of .10033622 or none. Any result under three (3) shows no significance of difference.

A study of Table VII shows there are more boys than girls in the visiting teacher group, while the normal group distribution shows more girls than boys. Fifty per cent more boys than girls were in the visiting teacher group. A review of statistical records kept by the visiting teacher for the past five years shows thexe were a majority of boys who recelvea this service. There is no statistical evidence to show why there is a difference. It may be due to the fact that boys of junior high school age are less apt to conform to prescribed school routine ana therefore present more problems, especially in scholarship, attendance, and conduct.

The following conclusions may be drawn from the

1 Formula for sienificance of difference.

$$
S=\frac{d}{\sqrt{\sigma_{1}^{2}+\sigma_{2}^{2}}}
$$

$S=$ sienificance of difference

$D=$ difference of standard errors of means

$\sigma_{1}^{2}=$ standard error of visiting teacher group

$\sigma_{2}^{2}=$ standard error of normal group. 
comparisons in Table VII: first, the visiting teacher does not draw cases proportionately by grade and sex from the school population; second, visiting teacher cases are in the same age groups as the normal cases in the respective grades; and third, there is no significance of difference statistically between the visiting teacher group and the normal group as to the mean I.Q.'s. The last conclusion is in Leeping with evidence found by a stuajy of chilaren showIng behavior difficulties made by Paynter and Blanchard. They found in a study of 230 children, handled by the National Committee for Mental Hysiene, that there is no correlation between intelligence levels as shom by the I. . ana presence or absence of behavior difficulties.?

The visiting teacher's work with individuals constantly brings out the major role played by the home and family, in regard to the child's adjustment and growth. The home and the family are essential factors in pupil adjustment, for it is through these institutions that patterns of attitudes and emotions are laid, that cannot be easily changed by other influences. The school is dealing with groups made up of individuals with various types of family and home backgrounds. In case work each situation is pe-

2 Richard $\mathrm{F}$. Paynter and Phyllis Blanchard, $A$ Study of Educational Achievement of Problem Children (New York: The Commonwealth Fund Division of Publications, 1929), p. 38 . 
culiar to each pupil, and must be welghed in the light of the total situation. There are certain questions, however, which can be answered in regard to homes and families of pupils. In Chapter I a study of the Highland Junior High School communty revealed a high type residential area. It follows that in such a community the homes and families will have a high socio-economic rating. To measure this rating each pupil in both the visiting teacher group and the normal group were given the Sims' questionnaire for socio-economic rating. 3 Puplls were given the questionnaire during the month of May, 1941, with the exception of the 9 A pupils in the visiting teacher group, who left the school in Febmary, 1941. They were given the questionnalre in December, 1940. In Table VIII is shown the results of the ratings by groups as they fall into the levels set up by the author of the test.

3 Verner M. Sims, Sims Score Card for SocioEconomic Status (Bloomington, IIlinois: Public school Publishing Company, 1927). 


\section{TABLE VIII}

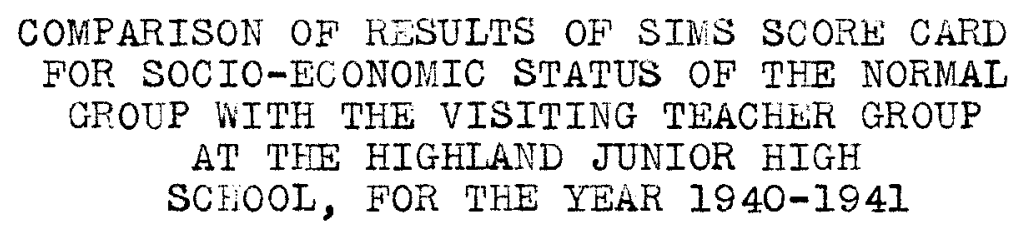

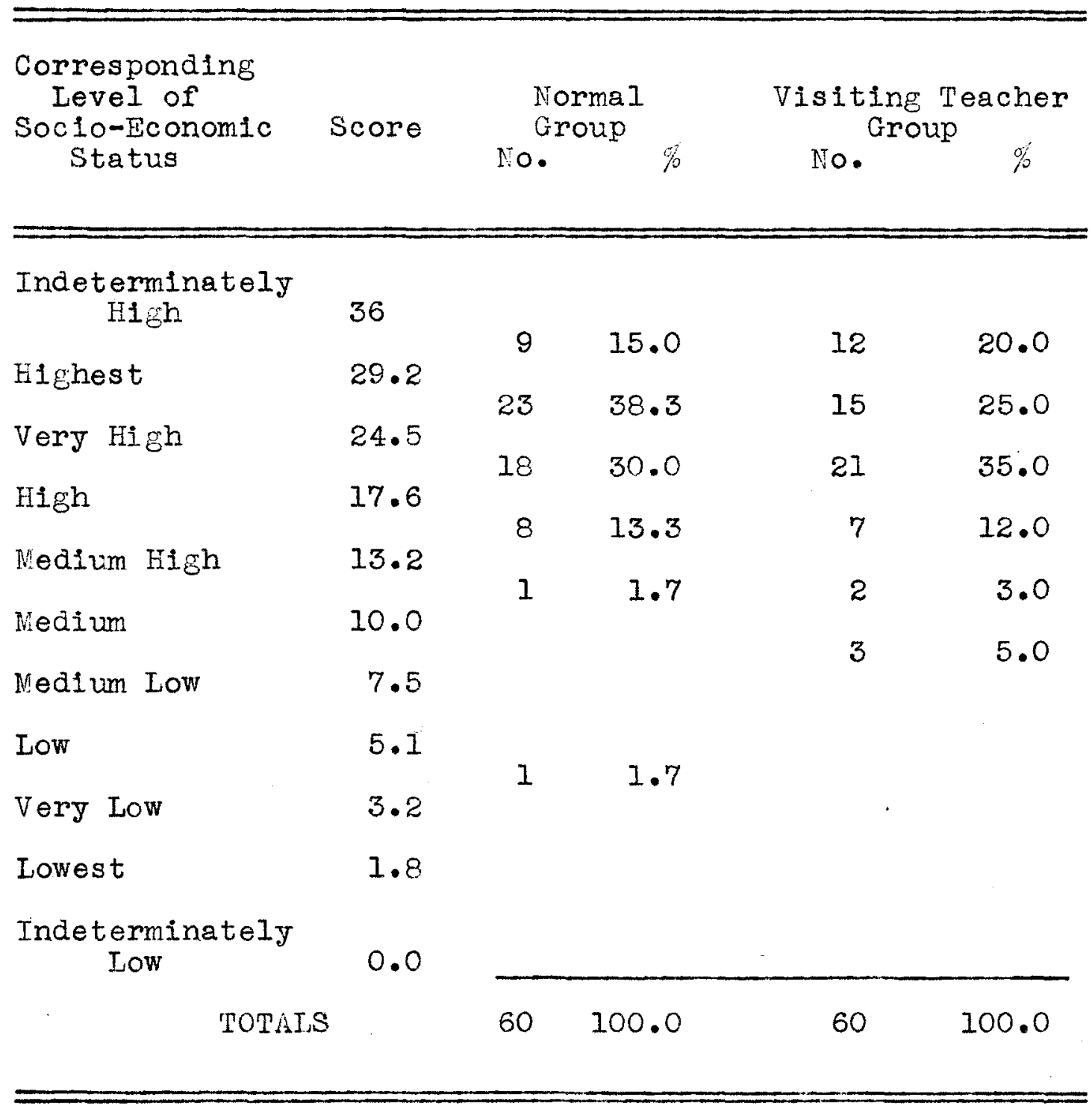

Median score for Normal group 28.5, Range 5-35. Median score for Visiting Teacher group 23.0, Range 8-35. Nean score for Normal group 24.60 Mean score for Visiting Teacher group 23.45 
The comparison of the results of sims Score card for socio-economic status of the normal group and the visitIng teacher group made in Table VIII, shows that in the different levels both groups have high ratings. Between the hiohest rating, "Indeterminately $\mathrm{H} 1 \mathrm{gh}$ ", and the next level, "Highest", there are nine pupils or 15 per cent of the normal group, and twelve pupils or 20 per cent of the visiting teacher group. Between the "Highest" level and "Very High" there were twenty-three puplls or 38.3 per cent of the normal group and fifteen pupils or 25 per cent of the visiting teacher group. From "Very High" to the next level, "High", there are eighteen pupils or 30 per cent in the normal group, and twenty-one pupils or 35 per cent in the visiting teacher group. There are eight pupils or 13.3 per cent in the normal group, and seven pupils or 12 per cent in the visiting teacher group in the level from "High" to "Medium High". In the level from "Medium High" to"Medium" there is one pupil or 1.7 per cent in the normal group, and there are two pupils or 3 per cent in the visiting teacher group. The lowest rating shown was made by one pupil or 1.7 per cent of the nomal group. This rating was between "Low" and "Very Low".

The formula for the significance of difference was applied using the mean scores of the two groups, 23.45 for the visiting teacher group and 24.06 for the normal 
group. The result of this was an answer of .1899 or less than one (1). As the answer is under three (3) there is no statistical significance of difference between the mean scores.

A study of Table VIII shows how closely the ratIngs of the two groups compare, with the majority of the pupil ratings between "Indeterminately High" and "High". From this comparison two conclusions can be drawn; first, the normal group has a high rating of socio-economic status; second, the visiting teacher group has a correspondingly high rating, showing that in this area visiting teacher pupils are of approximately the same socio-economic status as their fellow pupils.

The Idea suggested itself that the results of the Sims Questionnaire be compared with the results of the economic Erouping made by the princlpal and the visiting teacher and explained in the early part of this chapter. The latter was made as a step in obtaining the normal group, the representative group of the school population. As was stated in setting up these levels, they have meaning only in the economic levels within the Highland Junior High School. The Sims Questionnaire represents levels of socioeconomic status which were worked out to be used in all types of communities. The table on Page 77, Table IX, shows a comparison of the Sims ratings of the normal group and 
the visiting teacher group with economic ratings by the principal and the visiting teacher. The results of the economic groupings by the principal and the visiting teacher were placed opposite the suggested ratings of the Sims Questionnaire. 
TABLE IX

CONPARISON OF THE SIMS SCORE CARD RATINGS OF THE

NORMAI GROUP AND THE VISITING TEACHER GROUP WITH THE ECONOMIC RATINGS OF THE PRINCIPAL

AND THE VISITING TEACFER

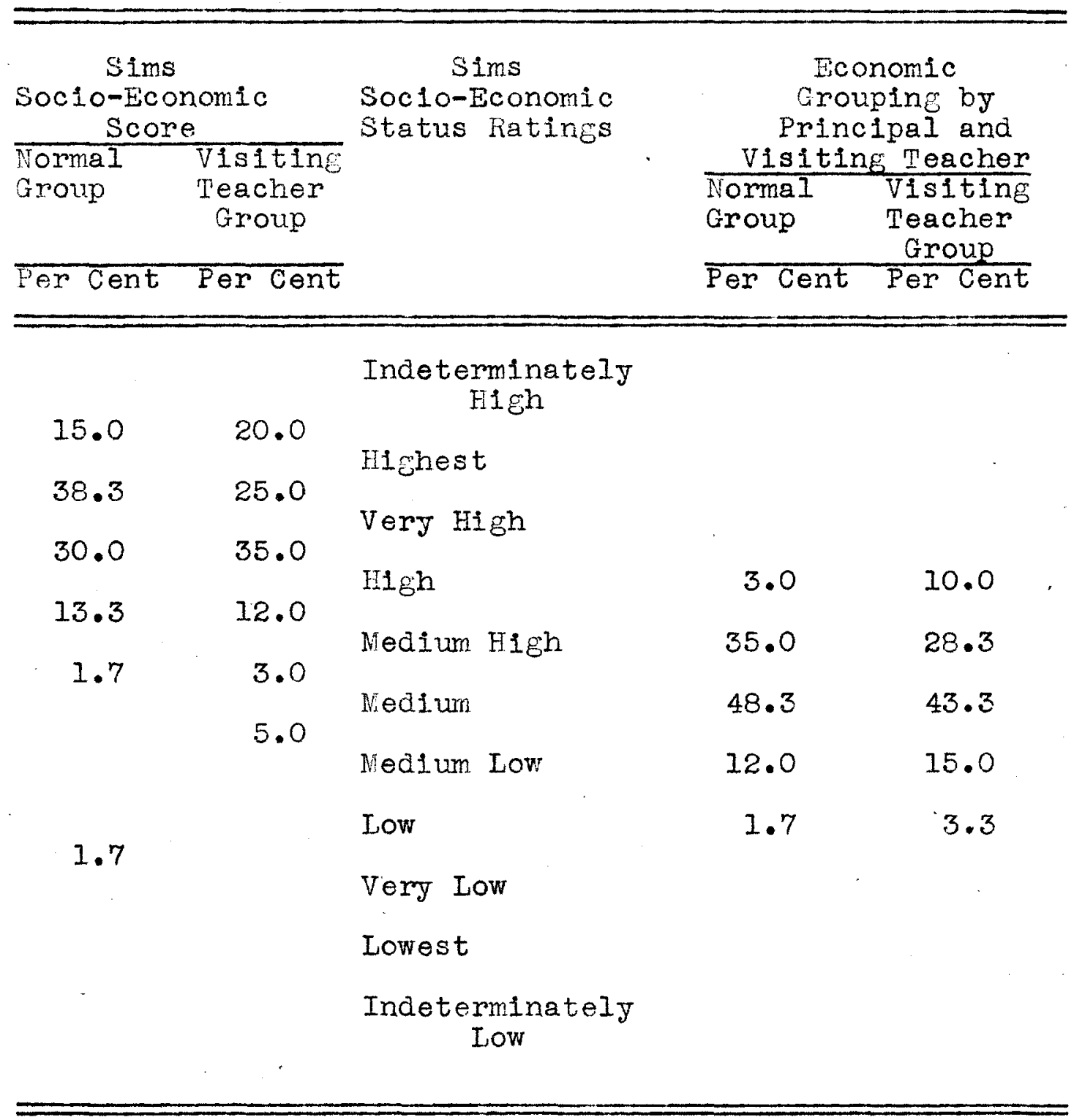


The results of the comparison in Table IX show that the socio-economic status ratings of the SIms questionnaire are very much higher for both groups. This was expected in the results of this comparison since the results in Table VIII indicated that according to the sims questionnaire both groups have high ratings. The "Medium" for the Highland Junior High School as grouped by the princlpal and the visiting teacher is not the "Medium" for the Sims questionnaire. Now, if the economic grouping which applies only to the Highland Junior High School were placed on the Sims Socio-Economic status Rating Scale, in their relative positions, the "Medium" for both groups would fall approximately between "Very High" and "Highest".

Another point which should be brought out in regard to the comparison made in Table IX, is that the Sims Questionnaire measures general culture and the social and economic background furnished by the homes of school children. ${ }^{4}$ The economic srouping of the principal and visiting teacher had as its primary object economic background. In the subjective grouping, however, it cannot be said that. the cultural and soclal status were always entirely disregarded.

4 Vemer 1.. Sims, Manual of Directions For the Sims Score Card of Socio-Economic status (Bloomington, Illinois: Public School publishing Company, 1927), p.3. 
It is interesting to note that if the rating of the principal and the visiting teacher were placed opposite that obtained from the Sims' Score many percentages vould be very close. Perhaps the estinates of the visiting teacher and principal were biased because of the fact that all their students come from relatively high economic levels.

In discussing the interpretation of results of the levels of socio-economic status of the Sims Questionnaire, Nr. Sims says:

Use of the word status implies relative position, and it is well to recoenize the fact that the condition being measured is usually of significance in connection with the group within which the child lives. The questions may not have like significance in different communities. To possess all the items called for in the score Card may in one community indicate an extremely high socioeconomic level, in another it may indicate but an average level. The status or condition bein measured is very much a relative matter.5

At the Highland Junior High School it is sometimes necessary in the treatment of a case to transfer a pupil to a school where the socio-economic level is lower. This is done so that the pupil may be with other companions of comparatively similar socio-economic status.

The comparisons made so far in this study in regard to families and homes have established the fact that both groups have high socio-economic ratings. In order to make a further study of home conditions as well as of the

5 sims, op. cit., pp. 10-11. 
out-of-school activities of pupils, a more detailed study of the questions of the Sims Questionnaire and other avaliable information on school records was compiled. The following comparisons made in Tables $X, X I, X I I$, and XIII, wiII show certain facts, relative to parents, physicel conveniences of homes, and out-of-school activities of puplls. It is of interest to determine if the visiting teacher group compares favorably with the normal Eroup in these areas. In Table $\mathrm{X}$ the schooling of parents in the two groups is compared.

TABLE $X$

CONPARISON OH SOEOOLIU OH PAFENS OF NORNAL GROUP WITH TIE VISITING TEACHIR GROUP AT THE FIGIIAND JUNIOR HIGE SCFOOL FOR IFE YEAR 1940-1941

Educaticn

of

Parents
Normal Group

Number Pei Cert.
Visiting Teacher

Group

\begin{tabular}{|c|c|c|c|c|c|}
\hline \multirow{2}{*}{$\begin{array}{l}\text { Attended } \\
\text { college }\end{array}$} & Father & 32 & 53.3 & 28 & 46.6 \\
\hline & Nother & 23 & 38.3 & 24 & 40.0 \\
\hline $\begin{array}{c}\text { Attended } \\
\mathrm{H} 1 \mathrm{~g} h\end{array}$ & Father & 56 & 93.3 & 54 & 90.0 \\
\hline School & Mother & 53 & .88 .0 & 52 & 86.6 \\
\hline
\end{tabular}

* Any college other than a business college upon completion of high school work. 
As shown in Table $X$ in the normal group thirtytwo fathers or 53.3 per cent and twenty-three mothers or 38.3 per cent attended college. In the visiting teacher group twenty-eight fathers or 46.6 per cent, and twentyfour mothers or 40 per cent attended college. As would be expected the percentage of parents in this area was high in both groups. The greatest difference appeared in the percentage of fathers attending college, with the normal group having 6.7 per cent more than the visiting teacher group.

In any mention of the environmental influences which shape and mould the individual's behavior, the family comes first. In the following table, Table XI, a comparison of the physical aspects of a normal parental situation is made. This comparison is especially significant in a study of visiting teacher work, as the effects of the child's home are of the first consideration in understanding his behavior. Psychologists and those working with children's problems are aware of the relative unimportance of extemal considerations as against the emotional relationships with the family.

Much stress was formerly placed upon "broken homes" as a cause of delinquency although recently less importance, is being attributed to this factor. Obviously not all children of broken or disorganized homes become delinquent. Increasing emphasis is being placed on the fact that the presence or absence of a complete fami- 
Iy group is less important than the quality of family life. Shle unquestionably children suffer from the disorganization of family life, the lack of emotional satisfactions which the family group should offer the child is of greater importance.6

In this study, nevertheless, it is of interest to point out that in the home situations compared in Table XI the visiting teacher group showed higher percentages than the normal Eroup.

6 Elsa Castendyck, "Behavior Problems," Social Work Year Book 1941, (New York: Russel Sace Foundation, I941), p. 53 
TABIE XI

- COMPARISON OF BKOKEN HOMES, WORKIMG MOTHERS, AND FATIERS IRREGULARLY AT HOME BECAUSE OF THEIR ENP IOYNENT, OF TIE NORMAI GROUP WITH THE VISITING TEACHER GROUP AT THE HIGHLAND JUNIOR HIGH SCHOOI FOR THE YEAR 1940-194I

\begin{tabular}{lcccc}
\hline $\begin{array}{c}\text { Home } \\
\text { Situations }\end{array}$ & $\begin{array}{c}\text { Nomal Group } \\
\text { Number Per Cent }\end{array}$ & $\begin{array}{c}\text { V.T. Group *** } \\
\text { Number }\end{array}$ \\
\hline $\begin{array}{l}\text { Broken Homes } * \\
\text { Work1ng Mothers } \\
\text { Fathers Irregularly } \\
\text { at Home }\end{array}$ & 6 & 10.0 & 10 & 16.6 \\
& 4 & 5.8 & 6 & 10.0 \\
\hline
\end{tabular}

* Homes where both parents are not living due to death, divorce, or separation.

** Visiting Teacher Group. 
Table XI shows that 10 per cent of the normal group come from broken homes, that is homes in which both parents are not living because of death, divorce, or separation, while there are 16 per cent of the visiting teacher group in this category. The comparisons in this table also show that there are 5.8 per cent of the normal group and 10 per cent of the visiting teacher group whose mothers are employed. Only mothers workine outside the home are considered in this group. The third comparison in this table, "Fathers irrecularly at home", refers to situations where for business reasons the father is at home only at week-ends, or even at less frequent intervals. The results of this comparison show there are 3.3 per cent of the normal group and 13.3 per cent of the visiting teacher group who fall under this heading.

A comparison of the physical aspects of the homes of the normal group and the visiting teacher group is made in Table XII. This comparison is of interest as it indicated the physical surroundings of homes. 
TABIE XII

COMPARISON OF HOMES OF NORMAL GFOUP WITH

VISITING TEACHER GROUP OF THE HIGHILAND

JUNIOR LIGE SCHOOL FOR THE YEAR

$1940-1941$

\begin{tabular}{lcccc}
\hline Tomes & \multicolumn{2}{c}{$\begin{array}{c}\text { Normal Group } \\
\text { Number Per Cent }\end{array}$} & $\begin{array}{c}\text { V.T. Group ** } \\
\text { Number Per Cent }\end{array}$ \\
\hline Own Room to Study & 50 & 83.3 & 56 & 93.3 \\
Servants & 38 & 63.3 & 35 & 58.3 \\
Room Ratio $*$ & & 1.60 & & 1.75 \\
\hline
\end{tabular}

* Number of rooms per persons ccoupying aweling.

** Visiting Teacher Group. 
Table XII shows that the percentage of pupils in the normal group who have rooms in which to study without distraction is 10 per cent lower than in the visiting teacher group. There is 5 per cent difference between the two groups in homes which have one or more servants. In room ratio there is a difference of .15 per cent in the two groups. The conclusion to be drawn from this table is that the physical aspects of homes of the visiting teacher group are not less desirable than those of the normal group.

$$
\text { Out-of-school activities of pupils are of vital }
$$

concern to the visiting teacher, first, as they tend to show a part of the child's life that is essential to his development, and second, as information relative to these activities is necessary for a complete picture of each pup11. Pupils at the Highland Junior High School often have many planned activities; such as music and dancing lessons, and Boy and Girl Scout activities. With some pupils participation in these wholesome activities is encouraged; sometimes it is found, however, that too much time is given to these things. In Table XIII a comparison is made to determine if the visiting teacher group takes part in the pursuits to the same extent as the normal group. 
TABLE XIII

COMPARISON UF OUT-OF-SCHOOL ACTIVITIES

OF NORNAL GROUP WITH THE VISITING

TEACHER CROUP AT THE HIGHLAND

JUNIOR HIGH SCHOOL FOR THE

YEAR 1940-1941

\begin{tabular}{lcccc}
\hline $\begin{array}{l}\text { Out-of-School } \\
\text { Activities }\end{array}$ & $\begin{array}{c}\text { Normal Group } \\
\text { Number }\end{array}$ & $\begin{array}{c}\text { V.T. Group ** } \\
\text { Number }\end{array}$ \\
\hline \hline $\begin{array}{l}\text { Nusic or Dancing } \\
\text { Iessons }\end{array}$ & 20 & 33.3 & 33 & 55.0 \\
Clubs & 38 & 63.3 & 33 & 55.0 \\
Norking Part Time & 2 & 3.3 & 2 & 3.3 \\
Miscelianeous * & 1 & 1.6 & 6 & 10.0 \\
\hline
\end{tabular}

This includes attending classes in gymnasium, Hebrew, horseback riding, and skating.

** Visiting Teacher Group. 
Table XIII shows that 33.3 per cent of the normal group and 55 per cent of the visiting teacher group take music and dancing lessons. Sixty-three and three tenths per cent of the normal group and 55 per cent of the visiting teacher group belong to clubs. This includes Boy and Girl Scout Clubs, as well as private clubs such as sewing and knitting groups and athletic organizations. The percentages in this table indicate that these activities are popular with both groups. It is interesting to note that there are 21.7 per cent more pupils of the visiting teacher group taking music and dancing lessons than of the normaI group. In Table XIII, also, the number and per cent of pupils in each group who have part time work, such as paper routes, helping in stores after school, and acting as delivery boys are compared. The same percentage of each group is engaged in this manner. Under the heading"miscellaneous activities" the visiting teacher group exceeds the normal group by 8.4 per cent.

The conclusions to be drawn from the compartsons made in Table XIII indicate that the visiting teacher group participates in regular scheduled out-of-school activities to a slight degree more than the normal group.

It must be pointed out that several pupils in the visiting teacher group gave too much time to these activities, to the neglect of school duties. In one known case 
a pupil showed serious mental anxiety brought about by too much pressure from school duties, Hebrew lessons, gymnasium classes, and other activities that regulated his time both day and night.

The following conclusions about the visiting teacher group can be drawn from the comparisons relative to home conditions and out-of-school activities of pupils made in Tables $X, X I, X I I$, and XIII: first, that parents of this Group have approximately as much schooling as parents of the normal group; second, that a greater percentage of pupils in the visiting teacher group live in homes where both parents are not present, where mothers are employed, and where fathers are not resularly at home at night because of their employment; third, that the physical conveniences of homes of the visiting teacher group are as good as those of the normal group; and fourth, that a slightly greater percentage of pupils of the visiting teacher group are engaged in regular out-of-school activities.

In Chapter I extra-curricular activities of the Highland Junior High School were discussed. It was pointed out that these activities are an essential part of the Junior High School program, and that pupils that participate in them are learning to make better social adjustments, to pursue interesting hobbies, or perhaps to find vocational interests and ways of satisfying personal needs. It will 
be shown how the normal eroup compares with the visiting teacher's group in participating in these activities at the end of the school year 1941. This comparison is shown in Table XIV.

TABLE XIV

CONPATISON OF TIE PERCMNTAGE OF PUPILS WHO PARTICIPATED IN EXTRA UURRIOUIAR ACTIVITIES OR RECEIVED SPECIAL EONORS OF THE TORNAL GEOTP .ITH THL VISTITMG IEACIEE GROUP OF TIE HIGHLAND JUNIOF IIIGE SCHOOL FOR TIE YEAR 1940-1941

\begin{tabular}{lcc}
\hline \multirow{2}{*}{ Activities } & \multicolumn{2}{c}{ Per Cent of Pupils } \\
Normal Group & Visiting Teacher Group \\
Athletics* & 41.6 & 30.0 \\
Clubs & 20.0 & 35.0 \\
Assemblies & 30.0 & 16.6 \\
School Paper & 0.0 & 5.0 \\
Miscellaneous** & 20.0 & 13.3 \\
& & \\
\hline
\end{tabular}

* This includes members of class teams, colf, and tennis tournament participants.

* This includes home room officers, captains of athletic teams, squad leaders in physical education, and school trumpeter.

Table XIV shows that the normal eroup's participation in extra-curricular school activities exceeds the visiting teacher group by 11.6 per cent in athletics, 13.4 per cent in assembly programs, and 6.7 per cent in the mis- 
cellaneous list. The visiting teacher group exceods the normal group by 15 per cent in participating in clubs, and by 5 per cent in school paper work. The greater percentage of club participants of the visiting teacher group is partly due to the efforts of those working with individuals in this group to interest them in these school activities. If John, a capable boy making low grades, is uninterested in his school work and it is found through interviews with him or his home that he is interested in photography, he is encouraged to join the Photography Club.

A study of health records of the normal group and the visiting teacher group reveals several outstanding facts. Information used in this comparison of health was obtained from the pupils' individual health cards. Physical examinations by the school physician or by private family phjsicians, dental examination by the school dentist and eye examination by the health counselor, were the means by which these data were obtained. These examinations are usually given when pupils are in the seventh grade; however, all new pupils in other grades are examined as soon as possible. When physical defects are found through these examinations, the health counselor informs the home as to the nature of the findings and recommends that the chilo be taken to his physician, eye specialist, or dentist, for more complete examinations and necessary treatment. Sometimes the 
school examiner may not definitely detemine whether a defect is present or not, but will recommend further examinations. In such cases where these recommendations were not carried out, the special difficulty is marked as a physical defect in this study. The results used in this comparison are physical defects which have not been corrected through the summer of 1941. In some instances the defects cannot be corrected; in others, the pupil is under treatment; while with other cases the recommendations have not been carried out.

Table XV shows a comparison of physical defects of the nornal group with the visiting teacher group. 
TABLE XV

PER CENT OF PHYSICAL DHFECTS OF THE NORMAL GROUP AS COMPARED WITH THE VISITING TEACHIR GROUP

OF PUPILS AT THE HIGHLAND JUNIOR HIGH

SCHOOI, FOR TEE YEAR 1940-1941*

Defects

- Visiting Teacher

Normal

Group

Per Cent

Group

Per Cent

\begin{tabular}{lcc}
\hline Vision & 10.0 & 0.0 \\
Weight & 20.0 & 10.0 \\
Posture & 21.6 & 10.0 \\
Dental & 15.0 & 3.3 \\
Tonsils & 20.0 & 8.3 \\
Physical Development & 28.3 & 15.0 \\
Iearing & 1.6 & 1.6 \\
Eeart & 3.3 & 1.6 \\
Glandular & 10.0 & 0.0 \\
Hernia & 3.3 & 1.6 \\
Flat $\mathrm{Peet}$ & 16.6 & 16.6 \\
Asthma & 1.6 & 0.0 \\
Eczema & 1.6 & 0.0 \\
Speech & 3.0 & 0.0 \\
Acne & & \\
\hline \hline
\end{tabular}

* From pupils' health caras 
Table XV on page 93 shows the percentages of physical defects of both groups broken down into specific difficulties. The visiting teacher group shows a greater percentage in all listed physical defects than the normal group except "flat feet". Sixteen and siy tenths per cent of both groups have various degrees of "flat feet". The table shows that the visiting teacher group has a greater percentage of defects than the normal group in the following: vision, which means a deviation from normal not corrected by classes, 10 per cent; weight, which might be either below or above the normal range, 10.0 per cent; posture, which is listed as "Fair" or "Poor", 11.6 per cent; dental, indicating need of care of the teetr, 11.7 per cent; tonsils, marked from plus one, enlarged, to plus four, infected, 11.7 per cent; development, meaning general physical development, 13.3 per cent; heart, which indicated irregularity, 1.7 per cent; flandular, which means physical indications pointing to glandular aisturbances, 10 per cent; eczema, 1.6 per cent; speech, 3.3 per cent; and acne on face, 5 per cent. This explanation of defects indicates that the seriousness of the difficulties has not been considered. They may ranee from minor defects, such as fair posture, to such difficulties as serious heart conditions. In the study of the physical defects isted in Table XV, an important point brought out in the comparison 
is the number and percentace of physical defects of the visiting teacher group which have to do with physical appearance. "Physical development", "Posture", and "weight" are among the highest percentages of defects in the visiting teacher group. pupil with defects in any of the areas is often the small boy or girl in the class or the overly developed one. It is not the purpose of this study to pursue this question further; however, more study of the question of physical appearance of problem cases is sugested by the facts brought out in this comparison.

$$
\text { It has becn showr in Table XV that the visiting }
$$
teacher group has a greater percentage of physical defects as listed on pupils' health cards than the normal group. The number of physical defects per case will be compared in Table XVI. 
TABLE XVI

CONPARISON OF NUMBER OF PHYSICAL DEFECTS PLR CASE OF NORMAL CASES WITH VISITING TEACHER CASES AT THE HIGHLAND JUNIOR HIGH SCHOOL FOR THE YEAR 1940-1941

\begin{tabular}{ccccc}
\hline $\begin{array}{c}\text { Normal Group } \\
\text { Number } \\
\text { Der Cent }\end{array}$ & $\begin{array}{c}\text { Number of } \\
\text { Physical Defects } \\
\text { Per Case }\end{array}$ & $\begin{array}{c}\text { V.T. Group* } \\
\text { Number } \\
\text { Per vent }\end{array}$ \\
\hline 23 & 38.3 & 0 & 10 & 16.6 \\
26 & 43.3 & 1 & 22 & 36.6 \\
10 & 16.6 & 2 & 13 & 21.6 \\
0 & 0 & 3 & 11 & 18.3 \\
1 & 1.6 & 4 & 4 & 6.3 \\
\hline
\end{tabular}

* Visiting Teacher Group. 
There are more physical defects per case in the visiting teacher group than in the normal eroup, as is shown by the comparison in Table XVI. One case or 1.6 per cent in the normal group and four cases or 6.3 per cent in the visiting teacher group had four physical defects per case. There were no cases in the normal group, and eleven cases or 18.3 per cent in the vistting teacher group, which had three physical defects per case. Ten cases or 16.6 per cent of the normal group, and thirteen cases or 21.6 per cent of the visiting teacher eroup had two physical defects per case; twenty-six cases or 43.3 per cent of the normal group, and twenty-two or 36.6 per cent of the visiting teacher group had one physical defect per case. The greater percentage of physical defects per case of the visiting teacher group might be expected, as pupils showing deviations from normal healtr standaras are often not able to keep up with the physically sound eroup. This often leads to maladjustment, poor scholarship, and irresular attendance. Obviously visiting teacher case work will include many of these pupils. Table XVI also shows that the physical defects considered in this study are present in more cases in the visiting teacher group than in the normal group. Thirty-eight and three tenths per cent of the normal group, as compared with 16.6 per cent of the visiting teacher group, have no physical defects. 
In this comparative study, the majority of physical defects of the visiting teacher group, both as to the number of pupils affected and the number of defects per child as shown in Tables XV and XVI, is significant. The lack of normal physical fitness cannot be overemphasized In dealjng with problems of behavior, shyness, aggressiveness, or any of the otrer types of personality maladjustment.

The results of the comparisons of physical defects of the two groups are especially significant to the visiting teacher. They indicate that perhaps visiting teacher treatment should include more attention and work in cooperation with the health counselor on the physical condition of visiting teacher's cases.

School attendance is especially the concern of the visiting teacher. It was pointed out in Chapter II that irregular attendance is regarded as a symptom only, and must be studied as other symptomatic behavior and treated accordingly. It follows that pupils whose records show irregular attendance at school are visiting teacher cases. Nany of these are included in the visiting teacher group in this study. In order to make a comparative study of attendance, only those cases in the visiting teacher group which were irregular attendance problems were selected to be compared with the normal group. This comparison is shown in Table XVII. 
TABLE XVII

COMPARISON OF SCHOOL ATTENDANCE OF THE NORNAL GROUP WITH VISITING TEACHER ATTENDANCE CASES

AT THE HIGHLAND JUNIOR HIGH SCHOOL FOR THE SCHOOL YEAR 1940-1941

School Terms

Normal Group

V.T. Group *

\begin{tabular}{llll}
\hline & Number of Pupils & 60 & 28 \\
FIRST & Per Cent of Days & & \\
Present & Per Cent of Days \\
Absent & & 95.6 & 82.2 \\
& Number of Pupils & 60 & 17.8 \\
SECOND & $\begin{array}{l}\text { Per Cent of Days } \\
\text { Present }\end{array}$ & 93.2 & 28 \\
& Per Cent of Days \\
Absent & 6.8 & 10.1 \\
\hline
\end{tabular}

* Visitine Teacher Group. 
Table XVII shows a comparison of school attendance of the normal group with those cases in the visiting teacher Eroup which showed attendance irregularities. During the first school term the sixty pupils of the normal group show 95.6 per cent days present and 4.4 per cent days absent. During this same period the twenty-eight pupils of the visiting teacher growp have 82.2 per cent days present, and 17.8 per cent days absent. The second term's record shows 93.2 per cent days present and 6.8 per cent days absent for the normal group as compared with 89.9 per cent days present and 10.1 per cent days absent for the visiting teacher group. The percentage of absence increased in the normal group during the second term. This rise is attributed to the prevalence of influenza and colds during this term. The percentage of absence for the entire school system showed an unusual rise during this term because of the epidemic throughout the city. ${ }^{7}$ Although this unfavorable absence showed in the normal group in Table XVII, the visiting teacher cases considered in this comparison showed an improvement of 7.7 per cent during this tern. The conclusion to be drawn from this comparison is that with a decrease of 2.4 per cent of the normal group in attend-

7 Director of Attendance, "Records of School Attendance for 1940-1941", (Louisville, Kentucky: Attendance Department, Board of Education). 
ance during the second term, and this increase of 7.7 per cent in the visiting teacher group, the visiting teacher. group's Improvement can be regarded as 10.1 per cent over that of the normal Eroup. This improvement in the visiting teacher cases indicates that visiting teacher service given in these cases was successful in improving their school attendance.

This comparison of school attendance does not give all the facts in regard to the visiting teacher's work in improving and maintaining good attendance. Irregular attendance, even though it might be a three or fourday absence scattered over several weeks, is often nipped in the bud by short treatment by the visiting teacher. Sometimes a home visit, an interview with the pupil, a change in his schedule, or soliciting his homeroom teacher's help, may be the means of working toward interesting the pupil who is showing signs of becoming an attendance problem. Preventative work in this area is often accomplished by the same treatments.

Lack of scholastic achievement of pupils is the most frequent reason given by teachers in referring cases to the visiting teacher. This observation proved true in the study of approximately 8,500 cases recorded by visiting teachers in the demonstration program of the National 
Committee of Visiting Teachers. ${ }^{8} \mathrm{Dr}$. Oppenheimer in his study of 1,307 visiting teacher cases also found this to be true. 9 These observations point to the importance of the part played by the visiting teacher in this field. Since the visiting teacher endeavors to assist in the improvement of scholarship, an attempt was made in this study to determine whether the visiting teacher group did improve in that respect more than the normal group. At first it seemed advisable to use for the comparative study of scholarship, only those cases which were referred because of poor scholarship. This plan was not carried out, however, because a study of teachers' grades of the sixty cases which make up the visiting teacher group revealed that in every case except four the pupil's grades were affected to some degree. It is easily seen that a pupil presenting a school problem whether it be unusual conduct, poor attendance, or any of the other problems will usually not achieve the best results in his school work. It follows that if the problem is eliminated or improved, scholastic improvement should also result. In regard to the four cases which showed no scholarship implications, it

\section{Jane Culbert, The Visiting Teacher at Work,} (New York: The Commonwealth Fund Division of Publications, 1929), p. 5 .

J. J. Oppenheimer, op. cit., p. 101. 
cannot be definitely said that teachers' grades were not affected, as it is possible that if the pupil had not presented some problem, he might have made better grades. It was therefore decided that the entire visiting teacher group of sixty cases be used in the scholarship comparisons. As the only statistical record for a comparison of pupils' scholarship is the teachers' grades, these were made the basis of the following comparisons.

at the end of each school term pupils in the Iouisville Public school system are given promotions or fallures depending upon the teachers' grades eamed during the previous period. The prevention of fallure of this kind is an important work of the school and necessarily a special concern of the visiting teacher. Her attention to the prevention of subject or grade fallure is first concerned with the individual, the effect it has on him, and the saving of time and energy for hir. Another important consideration is the money saved the school system. It is costly to provide means for puplis to repeat work. In the following tables, numbers XVIII and XIX, comparisons are made in regard to subject failure. Table XVIII shows a comparison of the number of pupils who failed in one or more subjects by terms. 
TABLE XVIII

CONPARISON OF NUMBER OF PUPILS VHO FAILED

IN ONE OF MORE SUBJECTS BY TERMS OF THE

NORNAL GROUP WITE TIES VISITING TLACEER

GROUP AT TEE IEIGHLAND JUNIOR HICH

SCHOOI FOR. THE YEAR 1940-1941

\begin{tabular}{|c|c|c|c|c|}
\hline School Term & $\begin{array}{l}\text { Norma } \\
\text { Number }\end{array}$ & $\begin{array}{l}\text { I Group } \\
\text { Per Cent }\end{array}$ & $\begin{array}{l}\text { Visiting } \\
\text { Number }\end{array}$ & $\begin{array}{c}\text { Teacher Group } \\
\text { Per Cent }\end{array}$ \\
\hline First & 6 & 10.0 & 21 & 35.0 \\
\hline Second & 6 & 10.0 & 16 & 26.6 \\
\hline
\end{tabular}

Table XVIII shows that there were the same number of pupils with fallures in the normal group during both terms. In the visiting teacher group twenty-one pupils or 35 per cent falled in one or more subjects the first term, while the second term there were sixteen pupils or 26.6 per cent who failed, a decrease of 8.4 per cent over the first term. Five less pupils in the visiting teacher group had to repeat one or more subjects because of failure to pass the prescribed work at the end of the second term than at the end of the first term. The evidence of improvement by the visiting teacher group is substantiated by the comparisons in Table XIX, which shows the number of subject failures by terms. 
TABLE XIX

CONPARISON OF NUMBER OF SUBJECT FAILURES OF TEE NORMAI GROUP WTTH THE VISITING TEACHER GROUP AT THE HIGHLAND JUNIOR HIGH SCHOOL FOR THE YEAR 1940-1941

School Term

Number of Subject F'ailures Normal Group Visiting Teacher Group

\begin{tabular}{lll}
\hline First & 7 & 28 \\
Second & 7 & 22 \\
& & \\
\hline
\end{tabular}

In Table XIX it is indicated that the number of failures by subjects in the normal group remained the same both terms, while in the visiting teacher group there was a decrease of six subject failures the second term.

The conclusions to be orawn from the comparisons of failures in Tables XVIII and XIX are that the saving to pupils in time and energy as well as the saving to the Board of Education in expense can in some measure be attributed to the visiting teacher service.

A more detailed picture of scholarship improvement can be made by a study of teachers' grades earned over a period of a school year. As visiting teacher work for the school year 1940-1941 is the focus of this paper, it was decided that a comparison of pupils of each group 
who improved, remalned the same, and made lower grades at the end of the school year than at the beginning, would show the general trend in regard to scholarship. This comparison is made in Table $\mathrm{XX}$.

TABLE XX

COMPARISON OF INPROVEMENT IN TEACHERS' GRADES OF THP NORMAL GROUP VITH THE VISITING TEACHER GROUP

AT THE HIGHLAND JUNIOR HIGH SCHOOL

FOR THE YEAR 1940-1941

\begin{tabular}{|c|c|c|c|c|}
\hline & $\begin{array}{l}\text { Nor } \\
\text { No. }\end{array}$ & $\begin{array}{l}\text { I Group } \\
\text { Per Cent }\end{array}$ & $\begin{array}{l}\text { Visiting } \\
\text { No. }\end{array}$ & $\begin{array}{c}\text { Teacher Group } \\
\text { Per Cent }\end{array}$ \\
\hline $\begin{array}{c}\text { Improved } \\
\text { Initial Nark }\end{array}$ & 28 & 46.6 & 48 & 80.0 \\
\hline $\begin{array}{l}\text { Same as } \\
\text { Initial Nark }\end{array}$ & 25 & 41.6 & 8 & 13.0 \\
\hline $\begin{array}{l}\text { Lower than } \\
\text { Initial Mark }\end{array}$ & 7 & 11.6 & 4 & 7.0 \\
\hline
\end{tabular}

Table XX compares the first marks the pupils of each group received auring the school year 1940-1941, with the last received for that year. The visiting teacher group has forty-eight pupils, 80 per cent, who improved their initial marks, eicht pupils, 13 per cent, who maintained the same marks, and four pupils, 7 per cent, who made lower marks. In contrast to this, the normal group had twen- 
ty-eight pupils, 46.6 per cent with improved marks, twentyfive puplis, 41.6 per cent, who had the same marks, and seven pupils, 11.6 per cent, who made worse marks. The difference between the two groups in number and per cent who made improvement is twenty pupils, 33.3 per cent, in favor of the visiting teacher group. flso the normal group had seven pupils, 11.6 per cent, and the visiting teacher group had four pupils, 7 per cent, who made lower marks at the end of the school year, givine an advantage of three pupils or approxirately 5 per cent in favor of the visiting teacher group.

The formula for the standard error of the difference between proportions in two samples was applied to determine if the improvement in marks of the visiting teacher group was statistically significant. 10 The result was the visiting teacher group showed 4.126 greater Improvement than the normal group. Any answer over three, (3), might be interpreted as showing a significance of difference. The improvement of the visiting teacher group is statistically significantly greater than the normal group.

10 Formula for standard error of the difference between proportions in two samples:

$$
r_{p_{1}}-p_{2}=\sqrt{\sigma_{1}^{2}+r 2^{2}}
$$


From this comparison it can be concluded that the visiting teacher group of cases improved more in scholarship during the year 1940-1941 than the normal group.

It is recognized that a comparative study of scholarship including only the time of visiting teacher supervision of pupils in her group might more conclusively point to the part played by her in bringing about improvement. This would require comparing teachers' marks of a different period of time for each pupil of the visiting teacher's group with the normal group. Each pupil of the normal group would then have to be matched with one of the visiting teacher's group. As the normal group was selected as a cross section of the entire school population, pairing pupils between groups for comparative purposes would not be possible.

It has been shown in the results of the comparisons of attendance and scholarship that the visiting teacher's group showed improvement over the normal group. It seems safe to assume that the visiting teacher's efforts in these areas were at least partially responsible for the improvement. Many other influences were certainly essential in bringing about this inprovement. Perhaps the most important influence was the part played by the classroom teachers. Whatever the visiting teacher may have done individually with a child, the success of his school adjustment was 
In the final analysis dependent upon the teacher. The other personnel workers of the school, namely the guidance counselor and the health counselor, have often been the primary forces responsible for bringing abovt improvement in a case. Also, the principal's influence with the pup1l and her guidance and interest as the school administrator have been essential in contributing to the improvement.

Teachers' Estimates of Results of Cases

As one of the chief functions of the visiting teacher is to help the school to study and adjust children who present problems, it was felt that an estirate of results of visiting teacher cases from this view point would be desirable. Those who are in the best position to estimate these results are the classroom teachers, as they are in dally contact with pupils in the school environment. One teacher was selected to answer a short questionnaire for each of the sixty visiting teacher cases. An effort was made to choose a teacher who had either referred the case originally or one who had been especially connected with the problem in treatment. This was done because in many cases a child presented a problem for one or perhaps several teachers, but was not considered a problem by all. The questionnaires were filled out at the end of the school year of 1940-1941. The teachers were asked to be as ob- 
jective as possible about the answers. The questionnaire contained each child's name and the following mimeographed points:

1. If you have considered this pupil a problem, do you think he or she has improved during the school year 1940-1941? (Check) Yes No

2. If he or she has improved tell briefly in what way.

3. Do you attribute the improvement in any part to the visiting teacher service? (Check) Yes No

Twenty teachers filled out the questionnalres for sixty pupils. Some teachers filled out several, while others gave their estirates for one or perhaps two. The numerous factors influencing the answers to these questions are recognized. Some of the factors which make the answers highly subjective are the teacher's attitude toward the pupil and toward the visiting teacher, the teacher's frame of mind at the time the questions were answered, and the difficulty of judging results of problems which have to do with the complexities of human nature. In Table XXI is compiled information from the questionnaires relative to the number and per cent, by grade and sex of those cases which irproved during the school year 1940-1941. 
TABLE XXI

TEACHERS' JUDGMENT OF RESUITS OF THE SIXTY*

VISITING TEACHER CASES AT THE HIGHLAND JUNIOR

HIGH SCFOOL FOR THI YEAR 1940-1041.

\begin{tabular}{|c|c|c|c|c|c|c|c|c|}
\hline \multirow{3}{*}{ Grade } & \multicolumn{4}{|c|}{$\begin{array}{l}\text { Pupils Showlng } \\
\text { Improvement }\end{array}$} & \multicolumn{4}{|c|}{$\begin{array}{l}\text { Pupils Showing } \\
\text { No Improvement }\end{array}$} \\
\hline & EO & Is & GI & Is & $\mathrm{BO}$ & s & Gir & \\
\hline & No. & $\therefore$ & No. & $\%$ & No. & $\%$ & No. & $\%$ \\
\hline 7 & 15 & 25.4 & 6 & 10.2 & 1 & 1.7 & 1 & 1.7 \\
\hline 8 & 7 & 11.8 & 0 & 0.0 & 2 & 3.3 & 1 & .1 .7 \\
\hline 9 & 15 & 25.4 & 8 & 13.7 & 2 & 3.3 & 1 & 1.7 \\
\hline Totals & 37 & 62.6 & 14 & 23.9 & 5 & 8.3 & 3 & 5.1 \\
\hline
\end{tabular}

* This table includes only fifty-nine cases, as one glrl in the eighth grade was not considered a problem by the teacher. This case was referred to the visiting teacher by the mother. 
Table XXI showed that of the sixty visiting teacher cases, fifty-nine were considered problems by the teachers. The pupil not considered a problem had been referred to the visiting teacher by the mother. The teachers believed there were thirty-seven boys, 62.6 per cent, who showed improvement. They were distributed by grades in the following way: fifteen, 25.4 per cent, in the seventh grade; seven, 11.8 per cent, in the eighth grade; and fifteen, 25.4 per cent, in the ninth grade. Fourteen girls, or 23.9 per cent, showed improvement. Six, 10.2 per cent, were in the seventh grade; none in the eighth grade; and eight, 13.7 per cent in the ninth erade. The five boys showing no improvement were distributed by rade in the following way: one, 1.7 per cent, in the seventh grade; two each, 3.3 per cent, in the eichth and nintr rades. A total of three cirls showed no improverent. There was one, 1.7 per cent, in each of the three crades.

In Table XXII is shown teachers' opinions as to the part visiting teacher service played in the improvement. 
TADIE XXII

TEACHERS' JUDGNENT OF VISITING TEACIEK'S SARVICES

AND OTESR FACTOPS RESPONSISLE FOR IMPROVENENT

OI CASES DURING OTH SOHOOI YEAR 1940-1941

AT TEE EIGIIAND JUNIOR HIGH SCHOOL

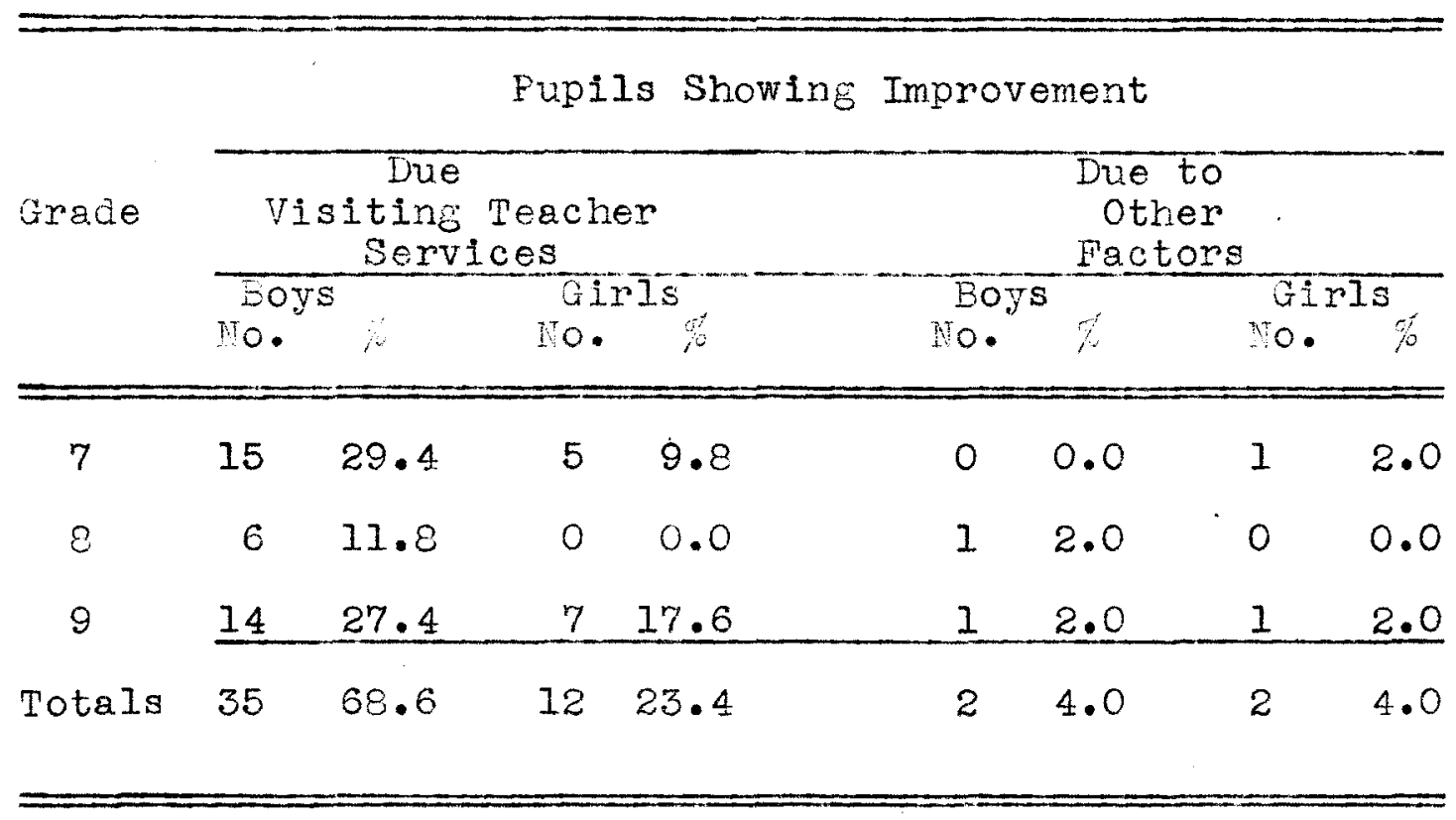


Table XXII shows that out of the fifty-one cases which showea improvement teachers thought there were thirtyfive boys, 68.6 per cent, and twelve girls, 23.5 per cent, whose improvement in some part could be attributed to the visiting teacher service, and two boys, 3.9 per cent, and two girls, 3.9 per cent, whose improvement was due to other factors.

From Tables XXI and XXII it can be concluded that according to teachers' opinions, a large majority, approximately 73 per cent, of the visiting teacher's group of cases showed some improvement, and that of those who improved, 92 per cent can be attributed in some part to the visiting teacher's work with the case.

A further analysis of the teachers' answers to questionnaires concerning pupils' improvements was made by compiling results of the statement,

If he or she has improved, tell briefly in what way.

The answers were recorded under these four headings which include all types of improvement mentioned: Scholarship; Attitudes, which includes pupils' attitudes toward work, toward companions, and toward the school in general; Conduct, which includes all types of behavior considered unusual; and School Attendance.

The results of this analysis are shown in Table XXIII, and include only the forty-seven cases which were accredited to the visiting teacher $s \in$ rvice. 
TABIE XXIII

TEACFERS' JUDGMENT OF INPROVEMENT SFOWN IN DIFETRENT AREAS, DUE TO VISITING TTACHER SERVICES

AT THE HIGHLAND JUNIOR HIGH SOHOOL

FOR THE YEAR 1940-1941

\begin{tabular}{|c|c|c|c|c|c|c|c|c|}
\hline \multirow{3}{*}{$\begin{array}{c}\text { Areas } \\
\text { of } \\
\text { Improvement }\end{array}$} & \multirow{2}{*}{\multicolumn{2}{|c|}{7 th }} & \multicolumn{4}{|c|}{ Grade* } & \multirow{2}{*}{\multicolumn{2}{|c|}{ Tote 7}} \\
\hline & & & & th & & 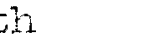 & & \\
\hline & $\begin{array}{l}\text { Boys } \\
\text { (15) }\end{array}$ & $\begin{array}{c}\text { Girls } \\
\text { (0) }\end{array}$ & $\begin{array}{l}\text { Boys } \\
(6)\end{array}$ & $\begin{array}{c}\text { Girls } \\
(0)\end{array}$ & $\begin{array}{l}\text { Boys } \\
(14)\end{array}$ & $\begin{array}{c}\text { Girls } \\
(7)\end{array}$ & $\begin{array}{l}\text { Boys } \\
(35)\end{array}$ & $\underset{(7)}{\text { Girls }}$ \\
\hline Scholarship & 7 & 2 & 1 & 0 & 7 & 4 & 15 & 6 \\
\hline Attitudes & 10 & 2 & 7 & 0 & 6 & 7 & 23 & 9 \\
\hline Conduct & 4 & 2 & 2 & 0 & 0 & 0 & 6 & 2 \\
\hline Attendance & 1 & 0 & 0 & 0 & 2 & 1 & 2 & 0 \\
\hline Totals & 22 & 6 & 10 & 0 & 15 & 12 & 46 & 17 \\
\hline
\end{tabular}

* The numbers fven in parentheses below the terms "Boys", "Girls", and "Totals", at the head of the table, indicate the number of cases in the respective columns. Percentages are not given as they would have no significance, because there is more than one area of improvement per case. 
Table XXIII shows that in the forty-seven cases in which teachers judged the visiting teacher service in Improvement, a total of $\mathrm{six}$ girls and fifteen boys showed improvement in scholarship. Improvements in attitudes were shown by a total of twenty-three boys and nine girls. Conduct improvements were shown by a total of six boys and two girls, and attendance improvements were shown by two boys and no girls.

The conclusions to be drawn from the results of the questionnaires compiled in Tables XXI, XXII, and XXIII show the general trend of teachers' opinions in regard to improvement of pupils who received visiting teacher service. 
SUMMAEY AND CONCLUSIONS 
The study of the Highland Junior High School and the district showed that the school is located in a high type residential district where the majority of influences tends to promote organization. It was cemonstrated that the school is a modern building planned to accomodate a varied program of activities suited to the needs of adolescents. The organization and administration of the school was shown to be based upon principles growing out of accepted junior high school practices. With this picture of the school and district as a backeround, the study focused attention on the visiting teacher's work in this setting and on the many types of problems with which the visiting teacher is concerned.

The purpose of this thesis was to evaluate the visiting teacher service and point out practices which might improve the work in the Highland Junior Migh School. This object was accomplished through a comparative study of the visiting teacher's group with the normal group and through a study of the results of a questicnnalre answered by teachers.

The normal Eroup, chosen by sampling from the school population, represents the average or normal of the school. It was proved that the statistical measures com- 
puted from this group of cases are sufficiently similar to the same measures if computed from the total school population. This being true, the following conclusions can be drawn from the comparative studies made in this chapter:

1. The group of visiting teacher cases studied contained 26.7 per cent more boys than girls in proportion to the school population. In other words the visiting teacher worked with 26.7 per cent more boys than girls.

2. I'he visiting teacher sroup measures equally as intelligent as the normal group. The visiting teacher is not dealing with a group which is below the average of the school in mental ablity.

3. The normal socio-economic status rating of the school is high, and the pupils with whom the visiting teacher worked have equally high ratings.

4. A family situation in which both parents are Iivine in the home, the mother not employed outside, and the father present after work, is considered a normal famiIy situation. A sreater number of pupils from the visiting teacher's group than from the normal group come from home situations which are not normal.

5. The physical aspects of the homes of both groups are equally desirable.

6. The visiting teacher's group has more cases in which there is participation in regulated out-of-school 
activities than does the normal group.

7. Fewer pupils in the visiting teacher group than in the normal group participated in the extra-curricular school activities.

8. A decided majority of the pupils in the visiting teacher group has more physical defects per case than those in the normal group.

9. School attendance of the visiting teacher group was below that of the school as a whole; however, there is a definite indication that this group improved during the second school term.

10. There were more pupils in the visiting teacher's group than in the normal group who failed in one or more subjects each term. However, the visiting teacher group made apparent improvement during the second term, while the number of failures in the nomal group remalned static.

11. The inprovement in teachers' grades made by the visiting teacher group during the school year was significantly greater than the improvement made by the normal group.

12. The orly two areas compared in this study in which the effectiveness of visiting teacher work can be measured are Attendance and Scholarship. In both of these areas it was proved that the group which came under the 
visiting teacher's care did improve.

Acting upon these conclusions, the visiting teacher could extend the field of her services and widen her activities by the following practices:

1. She might give special attention to the varlous physical defects of all cases handled by her by checking each case with the health counselor and working with her to eliminate disabilities. Although this practice is carried out at the Highland Junior High School in cases where there are indications of physical disabilities, it is felt that many presumably minor defects which might have been overlooked could be contributing to problems.

2. The importance of a normal home situation cannot be overlooked in dealing with pupils who present problems. Treatment of pupils who lack normal home situations must be directed toward compensating for the home deficiency. Each case needs careful study and specific treatment suited to the situation. In some cases the school can play a part in the treatment; in others the visiting teacher can strive to work out with members of the family compensating experiences for individual pupils.

3. The visiting teacher might look for too much regulated out-of-school activities of her cases as a factor in causing problems, and through the child and his home help to bring about a better situation. 
4. In certain cases the visiting teacher might encourage more participation in extra-curricular school activities. It must be pointed out, however, that this treatment must be specific for the individual pupil. on this subject Ruth Strang says:

Group activities offer different values to different individuals - to some progress along the lines of their special talents, to others rest and relaxation, to still others joy in creative work, fellowship, and cooperation in a common purpose or task. Because individuals select different elements from the same situation, undifferentiated prescription of activities cannot be effective. The activity must fit the individual. Unless the selection of a group activity is made on the basis of the pupil's needs, the potential values of group work will not be realized. It is important that students obtain satisfaction from constructive group experiences. 1

1 Ruth Strang, Group Activities in College and Secondary School (New York: Harper and Brothers Publishers, 1941), p. 28. 
BIBLIOGRAPHY 


\section{BIBIIOGRAPHY}

\section{A. BOOKS}

Bear, Robert Murray, The Social Functions of Education. New York: The Macmilian Company, 1937.

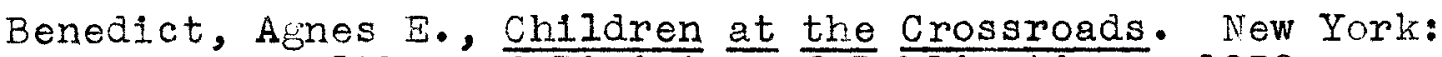
Commonwealth Fund Division of Fublications, 1930.

Briggs, Thomas H., The Junior High School. Boston: Houghton Miffin Company, $\overline{1920}$.

Carmelite, Janvier, "Visiting Teacher," Social Work Year Book 1937. New York: Russel Sage Foundation, 1937.

Caron Directory Company, Louisville Directory 1941. Louisville, Kentucky: Caron's Directory Company publishers, 1941 .

Castendyck, Elsa, "Behavior Problems," Soclal Work Year Book 1941. Hew York: Russel Sage Foundation, $\overline{1941 .}$

Culbert, Jane F., "The Visiting Teacher," College Women and the Social Sciences. Boston: The John Day Company, 1334 .

Culbert, Jane F., The Visiting Teacher at Work. New York: The Commonwealth Fund Division of Publication, 1929.

Dewey, John, How We Think. Boston: D. C. Feath and Company, 1910.

Drew, Julia K., "The Visiting Teacher in Minneapolis." The Principal and Fis Community Eileventh Yearbook. washington, D. C.: Department of Elementary School Principals, National Education Association, 1932.

Ellis, Nabel B., The Visiting Teacher in Rochester. New York: Joint Committee on Methods Of Preventing DeInquency, 1925.

Fretwell, Elbert K., Extra-Curricular Activities in Secondary Schools. Boston: Foughton Hifflin Company, IS3I.

Gallup, George, and Sol Farbes Rae, The Pulse of Democracy. New York: Simon and Schuster, 1940. 
Fall, Gladys E., "Changing Concepts in Visiting Teacher Work," Readings in Social Case work 1920-1938, Fern Lowry, editor. New York: Columbia University Press, 1939 .

Hamrin, Shirley A., and Clifford E. Erickson, Cuidance in the Secondary Schools. New York: D. Appleton-Century Company, 1939 .

Knox, Margaret, "The Visiting Teacher and the Problem Child," The Principal and Administration, Ninth Year Book.

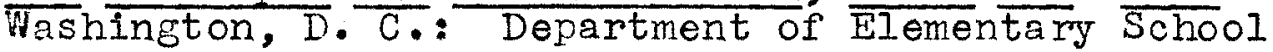
Princlpals, National Education Association, 1930.

Meredith, Lois A., "Relations Eetween Social Agencies and School," Readings in Social Case Work 1920-1938. Fern Lowry, editor, New York: Columbia University Press, 1939.

Nudd, Howard $W_{.}$, The Purpose and Scope of Visitinc Teacher Work. New York: Commonwealth Fund Division of Publications, 1830 .

Oppenheimer, Julius J., The Visiting Teacher Movement with Special Reference to Administrative Relationships. New York: Commonwealth Fund Division of Publications, 1925.

Paynter, Richard H., and Phylis Blanchard, A Study of Educational Achievement of Problem Children. New York: The Commonwealth Fund Division of Publications, 1929.

Prescott, Daniel A., Fmotion and The Educative Process. Washington, D. C.: American Council on Education, 1938.

Pringle, Ralph W., The Junior High School A Psychological Approach. New York: NicGraw-Iill Book Company, Inc., 1939.

Sayles, Nary Buell, editor. Child Guidance Cases. New York: Commonwealth Fund Division of Publications, 1928.

Sayles, lary Buell, The Problem Child at Home. New York: Commonwealth Fund ijision of Publications, 1929.

Sayles, Mary Buell, The Problem Child in School. New York: Commonwealth Fund Division of Publications, 1929.

Strang, Ruth, Group Activities in College and Secondary 
Schools. New York: Harper and Brothers, 1941.

United States Bureau of Census, Sixteenth Census of the United States 1940. Washington, D. C.: United

States Government Printing office, 1941.

Walker, Wlma, "Visiting Teachers," Soclal Work Year Book 1941. New York: Iussel Sage Foundation, 1041.

Wert, James E., Educational Statistics. New York: BcGraw-Hill Book Company, Inc., IO38.

Wickman, E. K., Children's Behavior and Teacher's Attitudes. New York: Commonwealth Fund Division of PubIications, 1928.

\section{B. PERIODICALS}

Anderson, Inez E., "OnIy one Visit," Joumal of the National Education Association, 28: $\overline{70 ; M a r c h, ~} 1839$.

Chase, Josephine, "Visiting Teacher at Work," Joumal of the National Education Association, 19: 245-46; November, 1930 .

Chase, Josephine, "State Cormissions' Recommendation for the Extention of the Visiting Teacher service, "School and Society, 30: 816-17, December 14, 1529.

Culbert, Jane F., "Visiting Teacher and the Problem Child," School Life, 15: 136-37, March, 1930.

Deffenbough, i. S., "Employment of Visiting Teachers Throughout The United States," School and Society, 26: 7. Juiy 2, 1927 .

Hall, Gladys E., "HelpIng School Children To Grow Emotionally," National Parent-Teachers, 32: 13-15, June, 1938.

Knox, M., "School, the Valadjusted Child and the Visiting Teacher," Ilementary School Journal, 28: 176-80, November, 1927.

Lathrop, E. A., "Hundred Visiting Teachers in the United States," School Life, 10: 84, January, 1925.

Iincoln, E. A., "Problem Children in Schools," School and 
Society, 23: 662-4, May 22, 1926.

Iingenfelter, Elizabeth, "Visiting Teacher," Journal of Education, 112: 56, July 21, 1930.

Mitcheil, R., "Day with A Visiting Teacher," Hygenia, 16: s31-2, October, 1938 .

Risen, M. L., "Relation of Lack of One or Both Parents to School Progress," Elementary School Journal, 39:52831, March, 1939.

Smalley, Ruth, "The Social Workers Use of the Interview with the Child," The Family, V 13266-270, December, 1920 .

Spencer, Gladys, "Visiting Teacher and Her Work." Childhood Education, 9: 369-71, April, 1933.

Stolz, H. R., "School Specialists and Community Agencles," National Educational Association Journal, 28: 69, March, 1939 .

Wightman, Clair S., "Visiting Teacher, a Unifying Agency in Education," Joumal of Educational Sociology, 10: 227 - 30, December, 1936 .

White House Conference on Children in a Democracy, Summary of General Report, National Educational Association Journal, 29: 69-70, March, 1940 .

Wile, I. S., "Visiting Teachers: Interpreting the School to the Home and the Fome to the School," Mental Hygiene, 18: 380-92, July, 1934.

vilcox, E. C., "What Parents Should Ask of a School," Parents Magazine, 16:24-5, Jv1y, 1941.

\section{BUILETINS AND PANPHLETS}

Assistant Superintendent of Elementary Education, School District Lines, Louisville, Kentucky, 1938.

Assistant Superintendent of Secondary Schools, The Organization and Administration of Instruction in the Junior High Schools of Louisville, Kentucky, pamphlet, 1936. 
The Courier-Journal and Louisville Times, Kentuckiana ... Its Potentialities, pamphlet, Louisville, Kentucky: The Courier-Joumal and The Louisville Times, 1941 .

Everett, Ealth M., "Visiting Teacher Service Today," Visiting Teacher Bulletin, published by the American Association of Visitine Teachers, May, 1940.

French, Lois Vieredith, "Trends in Visiting Teacher Work," Visiting Teacher Bulletin, June, 1935.

Sims, Verner Hi, Manual of Directions For The Sims Score Card of Socio-Economic Status. Bloomington, Ilinois; Public school Publishing Company, 1927.

School Directory, Louisville Public School Directory, 19401941 .

Works Projects Administration, Real Property Survey and Low Income Housing Area Survey 1. phlet, Volume I, 1939.

\section{UNPUBLISHED MAPERIAI}

Reasor, Marguerite, "The Contribution of Psychology to the Guidance Program of a Junior High School." Unpublished term paper. The University of Louisville, Louisville, Kentucky, 1940.

Peak, Naomi, "A Study of the George "Norris School and Community w1th Emphasis Upon The Personnel work of the School." Unpublished Master's Thesis, The University of Louisville, Lonisville, Kentucky, 1941.

E. OTHER SOTRCES

Boy Scouts of America, Loulsville Area Council. Files in Office, 1941 .

Director of Attendance, Records of School Attendance for 1940-1941. Records in files of Attendance Department, Board of Education, Louisville, Kentucky. 
Superintendent of Schools, Fifteenth Report of the Board of Education, Louisvilie, Kentucky. From July I, 1925 to June 30 , 1926. In files, Board of Education, Lovisvilie, Kentucky.

Girl Scouts of America, Louisville Area Council. Files in Office, 1941.

Johnson, Palmer 0., Professor of Education, University of Ninnesota. Letter Narch 13, 1942.

New Map of Greater Louisv1lle, Kentucky. Nap published by Pease Engineering Company, 1938 .

Works Projects Administration, A Study of Juvenile DeInquency in Louisvilie, 1935. Spot Map. Files of Community Chest Organization.

Yearly Report of Louisville Free Public Library for Year 1940-1941. Files of Lcuisville Free Public Library. 